\title{
Team-level predictors of innovation at work: A comprehensive meta-analysis spanning three decades of research
}

Citation for published version (APA):

Hülsheger, U. R., Anderson, N., \& Salgado, J. F. (2009). Team-level predictors of innovation at work: A comprehensive meta-analysis spanning three decades of research. Journal of Applied Psychology, 94(5), 1128-1145. https://doi.org/10.1037/a0015978

Document status and date:

Published: 01/01/2009

DOI:

10.1037/a0015978

Document Version:

Publisher's PDF, also known as Version of record

Document license:

Taverne

Please check the document version of this publication:

- A submitted manuscript is the version of the article upon submission and before peer-review. There can be important differences between the submitted version and the official published version of record.

People interested in the research are advised to contact the author for the final version of the publication, or visit the DOI to the publisher's website.

- The final author version and the galley proof are versions of the publication after peer review.

- The final published version features the final layout of the paper including the volume, issue and page numbers.

Link to publication

\footnotetext{
General rights rights.

- You may freely distribute the URL identifying the publication in the public portal. please follow below link for the End User Agreement:

www.umlib.nl/taverne-license

Take down policy

If you believe that this document breaches copyright please contact us at:

repository@maastrichtuniversity.nl

providing details and we will investigate your claim.
}

Copyright and moral rights for the publications made accessible in the public portal are retained by the authors and/or other copyright owners and it is a condition of accessing publications that users recognise and abide by the legal requirements associated with these

- Users may download and print one copy of any publication from the public portal for the purpose of private study or research.

- You may not further distribute the material or use it for any profit-making activity or commercial gain

If the publication is distributed under the terms of Article 25fa of the Dutch Copyright Act, indicated by the "Taverne" license above, 


\title{
Team-Level Predictors of Innovation at Work: A Comprehensive Meta-Analysis Spanning Three Decades of Research
}

\author{
Ute R. Hülsheger \\ Maastricht University
}

\author{
Neil Anderson \\ University of Amsterdam
}

\author{
Jesus F. Salgado \\ University of Santiago de Compostela
}

\begin{abstract}
This article presents a meta-analysis of team-level antecedents of creativity and innovation in the workplace. Using a general input-process-output model, the authors examined 15 team-level variables researched in primary studies published over the last 30 years and their relation to creativity and innovation. An exhaustive search of the international innovation literature resulted in a final sample $(k)$ of 104 independent studies. Results revealed that team process variables of support for innovation, vision, task orientation, and external communication displayed the strongest relationships with creativity and innovation ( $\rho$ s between 0.4 and 0.5 ). Input variables (i.e., team composition and structure) showed weaker effect sizes. Moderator analyses confirmed that relationships differ substantially depending on measurement method (self-ratings vs. independent ratings of innovation) and measurement level (individual vs. team innovation). Team variables displayed considerably stronger relationships with self-report measures of innovation compared with independent ratings and objective criteria. Team process variables were more strongly related to creativity and innovation measured at the team than the individual level. Implications for future research and pragmatic ramifications for organizational practice are discussed in conclusion.
\end{abstract}

Keywords: innovation, creativity, teams, meta-analysis, review

The last decades have witnessed a rapid growth in research interest into the facilitators and inhibitors of innovation in the workplace, which has led to an abundance of findings and practical suggestions. These have not always been in agreement with each other, because effect sizes vary substantially in magnitude and direction. Several years ago the first calls for integrative meta-analyses were simultaneously published by Anderson and King (1991) and by Damanpour (1991), and this has been repeated in several reviews since then (e.g., Anderson, De Dreu, \& Nijstad, 2004).

\section{The Need for Meta-Analysis at the Team Level of Analysis}

To date there exist only two published meta-analyses on innovation, both of which were restricted to the organizational level of

Ute R. Hülsheger, Faculty of Psychology and Neuroscience, Maastricht University, Maastricht, The Netherlands; Neil Anderson, Faculty of Economics and Business, University of Amsterdam, Amsterdam, The Netherlands; Jesus F. Salgado, Department of Social Psychology, University of Santiago de Compostela, Santiago de Compostela, Spain.

This research was funded by a fellowship (D/05/45773) from the German Academic Exchange Service to Ute R. Hülsheger during her postdoctoral studies at the University of Amsterdam Business School. We would like to express our sincere thanks to Günter W. Maier for letting us use his comprehensive database of innovation studies. Jesus Salgado was funded by Grant 2008-03592 of the Spanish Ministry of Science and Innovation.

Correspondence concerning this article should be addressed to Ute R. Hülsheger, Maastricht University, Faculty of Psychology and Neuroscience, Work and Social Psychology, P.O. Box 616, 6200 MD Maastricht, The Netherlands. E-mail: ute.hulsheger@psychology.unimaas.nl analysis (Camisón-Zornoza, Lapiedra-Alcamí, Segarra-Ciprés, \& Boronat-Navarro, 2004; Damanpour, 1991), and both therefore largely overlook important individual and team-level predictors. However, it is of course the case that within organizations new ideas will usually be proposed and pursued toward implementation by work teams. Therefore, for any creative proposal to be worked up toward an organizational-level innovation, these meso-analytical influences are critically important (Anderson \& King, 1993; Shalley \& Gilson, 2004; Shalley, Zhou, \& Oldham, 2004; West, 2002). As a consequence, innovation researchers have identified a multitude of team-level variables that might help or hinder innovation in organizations. The sheer volume of primary studies that has accumulated over the last 30 years is impressive. Yet the effects reported in these studies vary considerably with regard to both the magnitude and the direction of effects. For a couple of variables (e.g., task conflict), contradictory arguments and inconsistent findings have been presented (e.g., Kratzer, Leenders, \& Van Engelen, 2006; West, 2002). For instance, studies revealed both positive $(r=.56$; Chen, 2006) and negative $(r=-.41$; Lovelace, Shapiro, \& Weingart, 2001) correlations between task conflict and innovation. West and Farr's (1989) early evaluation of the state of the literature as a "jungle of inconsistent findings" (p. 17) is therefore still an apposite summary of the team-level innovation literature. Considerable variance in effect sizes makes it difficult to impossible to draw definitive and reliable conclusions about predictor-criterion relationships. This in turn impedes dependable suggestions for management practices and blurs pathways for future research.

The aim of the present study is therefore to conduct a comprehensive quantitative meta-analysis. The results of the meta- 
analysis benefit this field of research in several ways (see also Hunter \& Schmidt, 2004): First, the estimation of true mean relationships between team input and process variables and innovation allows reliable conclusions to be drawn about the most stable and powerful agents of innovation at the team level; thus, hands-on advice can be deduced for management practices. Second, it reveals which variables do not display generalizable main effects on innovation and seem to be situation specific and therefore need more research attention in the future. Third, we also investigate meaningful methodological moderator variables when our investigation of main relationships reveals sufficient study-tostudy variance to do so. Insights into these methodological moderators yield important implications for future research. Fourth, the meta-analysis also serves as a qualitative overview, identifying variables that have already been studied exhaustively as well as variables that have received only scant attention in the past.

An important distinction in this field of research is the differentiation between creativity and innovation. Innovation encompasses two stages: the generation of new ideas and their implementation (Amabile, 1996; West \& Farr, 1990; Woodman, Sawyer, \& Griffin, 1993). Creativity thus refers to the first stage of the innovation process - idea generation-and can therefore be seen as a subprocess of innovation, which encompasses idea generation and implementation. The aim of the present study is to investigate antecedents of idea generation as well as implementation. For the sake of brevity, we therefore refer mostly to the broader category - innovation-in the following, because it subsumes creativity.

\section{An Organizing Framework of Team-Level Antecedents of Innovation}

As a broad, overarching framework guiding the classification of the multitude of team-level variables studied as predictors of innovation, we built upon Hackman's (1987) widely accepted input-process-output (IPO) model of team performance (Ilgen, Hollenbeck, Johnson, \& Jundt, 2005; Salas, Stagl, \& Burke, 2004), which has also been adopted in the innovation literature (West \& Anderson, 1996). The IPO model therefore serves as a basis for classifying team-level variables that have been studied in primary studies into input and process factors. It is important to note that the current meta-analysis does not intend to test the overall IPO model of innovation. Rather, the model serves as a basis for classifying and coding team-level variables into meaningful subcategories. In addition to the IPO model, we consulted various reviews central to the innovation literature (Anderson et al., 2004; Anderson \& King, 1993; Maier, Streicher, Jonas, \& Frey, 2007; Shalley \& Gilson, 2004; West, 2002; Woodman et al., 1993) to differentiate specific categories within the broader input and process categories.

\section{Team Input Variables: Team Composition and Structure}

Extant theories of innovation have highlighted the role of core team input variables for innovation. In their interactionist theory of innovation, Woodman et al. (1993) specified that variables at the individual, team, and organizational level interact in promoting innovation in organizations. Specifically, at the team level the theory points to the role played by the composition and structural characteristics of teams in promoting innovative behavior in organizations. Further, West and Anderson (1996) adapted the basic IPO model of team performance to specify a theory of team innovation. With regard to input variables, they identified team composition and structural variables, such as team member diversity, team size, and tenure, as important antecedent conditions of innovation. We added task and goal interdependence to these variables, because they have received increasing attention in recent years (e.g., Van der Vegt \& Janssen, 2003).

Job-relevant and background diversity. The diversity of team members has repeatedly been discussed as a concomitant of innovation. Two forms of diversity in particular have been proposed: job-relevant diversity and background diversity (Shalley \& Gilson, 2004; West, 2002; Woodman et al., 1993). Job-relevant diversity refers to the heterogeneity of team members with respect to job- or task-related attributes, such as function, profession, education, tenure, knowledge, skills, or expertise (Milliken \& Martins, 1996; Pelled, Eisenhardt, \& Xin, 1999). It has been suggested that this kind of diversity is conducive to team innovation (Woodman et al., 1993). First, the contention is that by staffing a team with diverse members, a broad array of expertise, skills, and knowledge can be assembled within the team, which helps the team solve the complex task of developing new products or procedures. Second, if the individual team members have different kinds of backgrounds, the team is exposed to a variety of divergent perspectives and approaches, which stimulates creativity-related cognitive processes (Perry-Smith, 2006). Third, team diversity triggers communication with members outside the team, which in turn leads to the incorporation of diverse kinds of information and broadens team members' perspectives (Perry-Smith \& Shalley, 2003; West, 2002). These positive effects of diversity on team innovation are attributable to the diversity of cognitive resources.

In contrast, background diversity describes non-task-related differences such as age, gender, or ethnicity (Milliken \& Martins, 1996; Pelled et al., 1999; Webber \& Donahue, 2001). Unlike job-relevant diversity, background diversity does not evoke cognitive resource diversity (Webber \& Donahue, 2001). Instead, it may entail a number of consequences that interfere with innovative endeavors (Milliken \& Martins, 1996; Van der Vegt \& Janssen, 2003). Background diversity may lead to communication problems and difficulties in resolving opposing ideas and reaching consensus within the team. However, the ability to discuss opposing ideas, integrate divergent viewpoints, and reach consensus is vital for the creation and implementation of new ideas. We therefore hypothesize a differential relationship between innovation and job-relevant and background diversity:

Hypothesis 1: Job-relevant diversity (H1a) is positively related to innovation, whereas background diversity (H1b) is negatively related to innovation.

Task and goal interdependence. Past innovation literature has distinguished between task and goal interdependence. Task interdependence refers to the extent to which team members are dependent on one another to carry out their tasks and perform effectively. Goal interdependence, or outcome interdependence, describes the extent to which team members' goals and rewards are related in such a way that an individual team member can only reach his or her goal if the other team members achieve their goals 
as well (Saavedra, Earley, \& Van Dyne, 1993; Van der Vegt, Emans, \& Van de Vliert, 1999; Van der Vegt \& Van de Vliert, 2002). Although much is known about the relationship between task and goal interdependence and team performance, innovation research has only started to study interdependence as an antecedent to innovation (Van der Vegt \& Janssen, 2003). There are logical reasons to expect positive relationships between task and goal interdependence and innovation, as both stimulate interpersonal interaction, communication, and cooperation within the team (Van der Vegt et al., 1999; Van der Vegt \& Van de Vliert, 2002). Only by interacting with each other can team members exchange ideas, discuss divergent viewpoints, and integrate and evaluate them to create high-quality products or suggest innovative procedures. As Bledow, Frese, Anderson, Erez, and Farr (in press) have suggested in their theory of conflicting demands and ambidexterity in innovation, these interactions are liable to lead to divergent opinions and perspectives; consequently, the management of these unavoidable differences between team members will entail the regulation of such low-level conflicts and ultimately lead to innovative solutions.

Compared with task interdependence, goal interdependence might be more effective to encourage communication and cooperation. With cooperative goals in place, team members want each other to perform effectively for their mutual benefit. Individuals pull together, help each other, and discuss different viewpoints to optimize performance, which in turn benefits the team as a whole as well as every team member (Tjosvold, Tang, \& West, 2004; Van der Vegt \& Janssen, 2003). In sum, it is expected that task and especially goal interdependence facilitate communication and cooperation and stimulate critical discussions and the synthesis of different viewpoints. This, in turn, is expected to be linked to innovation.

Hypothesis 2: Task (H2a) and goal interdependence (H2b) are positively related to innovation.

Team size. Stewart (2006) pointed out that larger teams might be beneficial for the completion of difficult tasks in uncertain, complex environments. Only teams with sufficient members might be able to provide a wide array of resources, expertise, skills, and knowledge to complete complex tasks. The production and implementation of creative ideas is an ill-defined, complex task rather than a routine task. We therefore propose that team size is positively related to innovation, because in larger teams a wider array of diverse viewpoints, skills, and perspectives is likely to be found. This is in line with research suggesting a positive link between organization size and innovation (Anderson \& King, 1993; Kimberly \& Evanisko, 1981; Payne, 1990). Another hint on the positive relationship between team size and innovation comes from the brainstorming literature, which shows that both the number and quality of creative ideas increases with group size (Bouchard \& Hare, 1970; Gallupe et al., 1992).

Hypothesis 3: Team size is positively related to innovation.

Team longevity. It has been asserted that teams may become less innovative over time as they become more susceptible to groupthink, more homogeneous, and less inclined to be critical and to challenge the status quo (West \& Anderson, 1996). Katz (1982) argued that members of long-tenured teams tend to become increasingly focused on their own team and isolate themselves from external influences. Using a sample of research and development (R\&D) project teams, Katz provided evidence that with increasing tenure, teams displayed lower levels of communication with experts outside their own project group or organization. External contacts, however, are vital for innovation, because they provide teams with new information and inspiring impulses. Further, longtenured teams develop routine work patterns and stable structures they are unwilling to change as they give them a sense of security. Moreover, through socialization processes and shared experiences, team members develop more homogeneous viewpoints over time (Katz, 1982; West \& Anderson, 1996). This suggests that team longevity hinders the generation and implementation of new and useful ideas.

Hypothesis 4: Team longevity is negatively related to innovation.

\section{Team Process Variables}

Several theories of team innovation have ascribed a prominent role to team process variables in explaining team innovation. The interactionist theory of innovation (Woodman et al., 1993) suggests links between team cohesion as well as communication patterns and team innovation. In their theory of team innovation, West and colleagues (West, 1990; West \& Anderson, 1996) specified four additional team process variables that promote team innovation: vision, participative safety, support for innovation, and task orientation. These have subsequently been replicated in several studies internationally (Anderson \& West, 1998; Brodbeck \& Maier, 2001; Mathisen, Einarsen, Jorstad, \& Bronnick, 2004; Ragazzoni, Baiardi, Zotti, Anderson, \& West, 2002). These four dimensions serve to structure recurrent themes that have been researched in primary studies, and we therefore drew upon West's typology to identify and distinguish these four core team process dimensions.

We further extended Woodman's and West's typologies by adding task and relationship conflict to their list of variables. In recent years, innovation researchers have referred to socialpsychological theories of intragroup conflict to investigate how task and relationship conflict contributes to team innovation (e.g., De Dreu, 2006; Jehn, 1995; Pelled et al., 1999).

In developing a set of specific hypotheses on the relationship between team process variables and innovation, we built upon these theories. Further, we drew on a comprehensive theory of team adaptation (Burke, Stagl, Salas, Pierce, \& Kendall, 2006). Burke et al. (2006) extended the IPO model and presented a cyclical model of adaptive team performance. Although team adaptation and team innovation certainly cannot be treated as synonyms of the same construct, Burke et al. acknowledge that the constructs share important commonalities. Accordingly, team innovation is seen as a subfacet of team adaptation, and selected core team processes involved in team adaptation also apply to team innovation. Finally, in developing specific hypotheses we integrated proposals from the theory of conflicting demands and ambidexterity put forward recently by Bledow et al. (in press). This theory posits that differences of opinion and conflicting views are inherent to any innovation process at both the individual and the team level of analysis. 
Vision. "Vision is an idea of a valued outcome which represents a higher order goal and motivating force at work" (West, 1990, p. 310). This dimension assesses the extent to which team members have a common understanding of objectives and display high commitment to those team goals. Accordingly, this dimension has also been referred to as "clarity of and commitment to objectives" (West \& Anderson, 1996, p. 682). If vision is high, team and organizational goals are clear to team members; they are highly valued and visionary in nature and perceived as attainable, and team members feel committed to these goals. Clearly stated goals help team members to channel their efforts; they may give their work meaning, and in turn, they may motivate individuals toward enhancing their innovative performance. Besides West and colleagues (West, 1990; West \& Anderson, 1996), various other researchers have pointed out that for a team to be innovative, team members need to be committed to team objectives and organizational goals and share a sense of purpose and responsibility (e.g., Cardinal, 2001; Gilson \& Shalley, 2004; Rickards, Chen, \& Moger, 2001).

\section{Hypothesis 5: Vision is positively related to innovation.}

Participative safety. Participative safety is characterized by two components: participation in decision making and intragroup safety. Participation in decision making refers to the extent to which team members are involved in decision-making processes and assesses whether they share information and listen to each other's ideas. When people can participate in decision making, when they have influence and feel free to speak up, they show higher commitment and tend to invest more energy in their work (West \& Anderson, 1996). Intragroup safety refers to a nonthreatening psychological atmosphere within the team that is characterized by trust and mutual support. This aspect is closely linked to the concept of psychological safety, proposed by Edmondson (1999). Members of teams characterized by trust and a nonthreatening interpersonal climate are more inclined to come up with new ideas, due to a lack of concern about negative judgment by others (West, 1990). Similarly, the theory of team adaptation (Burke et al., 2006) suggests that psychological safety serves three important functions that are closely linked to team innovation. First, psychological safety contributes to plan formulation. By promoting interpersonal risk taking, psychological safety enables team members to speak up and contribute their idiosyncratic ideas and viewpoints during plan development even if these stand counter to the common group belief. Second, psychological safety facilitates plan execution by affecting the degree to which team members accept mutual performance monitoring, by fostering communication between team members, and by promoting back-up behavior. Third, psychological safety promotes team learning because it encourages team members to discuss their errors openly, ask questions, seek feedback, and reflect on alternative viewpoints (see also Edmondson, 1999).

A supportive, cooperative work atmosphere, where coworkers socialize and help each other and collaborate in problem solving, is thus expected to be conducive to innovation (e.g., Amabile, Conti, Coon, Lazenby, \& Herron, 1996; Keller, Julian, \& Kedia, 1996; Tiwana \& McLean, 2005).
Hypothesis 6: Participative safety is positively related to innovation.

Support for innovation. Support for innovation describes the "expectation, approval and practical support of attempts to introduce new and improved ways of doing things in the work environment" (West, 1990, p. 315). In a work environment where innovation is supported and there are articulated and enacted norms for innovation, attempts to innovate that are not successful are more likely to be tolerated, and team members may be more likely to take risks to implement new ideas (King, Anderson, \& West, 1991; Sethi, Smith, \& Park, 2001). Therefore, innovations are more likely to occur if the organization and the work team are perceived as open to change, if they encourage and value new ideas and publicly recognize and reward them, and if support for new ideas and their implementation is provided by managers, supervisors, and coworkers (Amabile et al., 1996; Madjar, Oldham, \& Pratt, 2002; Scott \& Bruce, 1994; Shin \& Zhou, 2003).

Hypothesis 7: Support for innovation is positively related to innovation.

Task orientation. Task orientation, which has also been called climate for excellence (West, 1990), describes "a shared concern with excellence of quality of task performance in relation to shared vision or outcomes" (West, 1990, p. 313). Teams high on this dimension are striving for the highest standards of performance achievable. This is evidenced by mutual monitoring and feedback and by regular appraisals of ideas and performance. Task orientation subsumes the subconstruct task reflexivity, which refers to the process in which the team reflects upon the team's objectives, strategies, and procedures, and evaluates each other's work to improve team effectiveness and outcomes. This in turn is meant to lead to the exploration of opposing opinions and the consideration of alternatives and thereby to improve the quality of decisions and ideas (Somech, 2006; Tjosvold et al., 2004; Wong, Tjosvold, \& $\mathrm{Su}, 2007$ ). In a similar vein, the theory of team adaptation (Burke et al., 2006) considers mutual performance monitoring and feedback, as well as critical reflection on team goals, to be important functions of plan execution, which is one of the processes involved in adaptive and innovative team performance. Further, Shalley (2002) pointed out that task orientation is equivalent to intrinsic motivation, which has been stressed as a prerequisite for creativity at the individual level of analysis (Amabile, 1996; Patterson, 2002; Shalley \& Perry-Smith, 2001; Shalley et al., 2004).

Hypothesis 8: Task orientation is positively related to innovation.

Cohesion. Cohesion has a long history in psychology (Festinger, 1950; Lott \& Lott, 1965; Seashore, 1954), and it is one of the most widely studied team characteristics (Kozlowski \& Bell, 2003; Kozlowski \& Ilgen, 2006). Cohesion refers to the commitment of team members to their work team and their desire to maintain group membership (Lott \& Lott, 1965). Different conceptualizations of team cohesion can be found in the literature (see Kozlowski \& Ilgen, 2006, for a review). Some conceptualize it as a unitary construct, focusing mainly on the degree of attraction among team members, whereas others differentiate between the facets of interpersonal attraction, task 
commitment, and group pride (Beal, Cohen, Burke, \& McLendon, 2003; Mullen \& Copper, 1994). Innovation researchers have tended to regard cohesion as a necessary precondition for innovative work behavior (West \& Farr, 1989; Woodman et al., 1993). A high personal attraction among team members creates a psychologically safe environment in which team members feel free to challenge the status quo and explore new ways of doing things (King et al., 1991; West \& Wallace, 1991). The contention that individuals are more willing to take risks in situations in which they have reliable bonds with important others and feel that they can rely on their support has parallels in other areas of psychology, such as developmental and clinical psychology (West, 1990). Theories of child development contend that children who are securely attached to their mothers engage in more exploratory and learning behavior than their anxiously attached counterparts (Ainsworth, 1979). Furthermore, team members who have strong feelings of belongingness and feel attached to other team members are more likely to cooperate, interact with each other, and exchange ideas.

Hypothesis 9: Cohesion is positively related to innovation.

Internal and external communication. Various researchers have focused on communication as a major source of innovation (e.g., Keller, 2001; Payne, 1990). The contention is that communication enables the sharing of information and ideas, which is a viable source of innovation. Researchers differentiate between internal and external communication (Keller, 2001). Especially if complex problems have to be addressed, regular, high-quality communication is indispensable in that it allows team members to share their knowledge and past experiences and exchange and discuss ideas, which is especially important for the generation of new ideas (Van de Ven, 1986). Likewise, the theory of team adaptation (Burke et al., 2006) ascribes to communication a pivotal role for the plan execution phase in which team members need to monitor each other, help each other out, and provide constructive feedback. Communication is the necessary basis for mutual monitoring, back-up behavior, and the provision of feedback. Consequently, communication is vital not only for idea generation but also for the implementation of new ideas.

In a similar vein, external communication fosters innovation. Taking a social networks perspective, Perry-Smith and Shalley (2003) underlined the importance of interpersonal relations with people outside one's own team or organization. Interactions with other functional areas enhance the likelihood of obtaining new knowledge and disclose new perspectives, which spark the development of new ideas or the adoption of new ways of doing things. Many researchers share this perspective and have provided evidence for the positive relationship between external communication and innovation (Ancona \& Caldwell, 1992b; Andrews \& Smith, 1996; Denison, Hart, \& Kahn, 1996; Keller, 2001; Payne, 1990).

Hypothesis 10: Internal communication (H10a) and external communication $(\mathrm{H} 10 \mathrm{~b})$ are positively related to innovation.

Task and relationship conflict. Although it is perhaps counterintuitive at first sight, conflict may be beneficial for innovation (Jehn, 1995; Pelled, 1996). Conflict research dates back to Deutsch's (1973) early theory of cooperation and competition. Refining the theory of intragroup conflict, researchers later started to differentiate between task and relationship conflict (e.g., Jehn, 1995).

Task conflict refers to "disagreements among team members about the content of the tasks being performed, including differences in viewpoints, ideas, and opinions" (Jehn, 1995, p. 258). This kind of conflict is conducive to innovation: Task-related disagreement among team members triggers information exchange, thorough exploration of opposing opinions, reevaluation of the status quo, and scrutiny of the task at hand. This in turn fosters the generation of new ideas and solutions and improves problem solving (Shalley \& Gilson, 2004; Tjosvold, 1985; West, 2002). Similarly, Bledow et al. (in press) have argued that conflict is inherent in innovation and necessary for it to occur and that the constructive management of these unavoidable contra-positions leads to the successful implementation of greater innovation in the workplace. Support for this position also stems from socialpsychological research on decision making, which shows that dissent leads to higher consideration of unshared information in groups and thereby enhances decision quality (Brodbeck, Kerschreiter, Mojzisch, Frey, \& Schulz-Hardt, 2002). In a similar vein, it has been argued that minority dissent, which is conceptually and empirically related to task conflict, reduces conformity and consensus-seeking and enhances cognitive complexity and divergent thinking, and thereby innovation (De Dreu \& West, 2001).

Relationship conflict describes social-emotional conflicts stemming from interpersonal disagreements (Jehn, 1995). Unlike taskrelated conflict, interpersonal, emotional conflict causes negative psychological reactions like strain, fear, anger, and frustration. These feelings absorb energy and distract team members from performing their tasks. In social-psychological theories of interpersonal conflict, it has been suggested that social conflict narrows the range of attention, produces rigid thinking, and reduces cognitive complexity (Carnevale \& Probst, 1998; Deutsch, 1969). Interpersonal conflict thus hinders information processing and interferes with cognitive functioning of individuals. Moreover, relationship conflict undermines team functioning to the degree that anger and frustration impede effective communication within the team and reduce team members' receptiveness to each others ideas (Baron, 1991; Jehn, 1995; Pelled, 1996).

Consequently, we expect differential relationships for task and relationship conflict with innovation.

Hypothesis 11: Task conflict (H11a) is positively related to innovation, whereas relationship conflict (H11b) is negatively related.

\section{Moderating Influences on Antecedent-Criterion Relationships}

Besides our investigation of the links between team-level variables and innovation, the present study aims at detecting moderators of these overall relationships. By focusing on two important but previously uninvestigated methodological moderatorsmeasurement level and measurement method-we seek to explain the variability of findings in the research literature.

\section{Measurement Level}

Researchers have examined innovation at two different measurement levels: individual and team. Individual-level research 
focuses on the work-role innovation of individual employees and is usually assessed by self, supervisor, or peer ratings (e.g., Axtell et al., 2000; Miron, Erez, \& Naveh, 2004; Shin \& Zhou, 2003); by the number of creative suggestions made by an employee (Oldham \& Cummings, 1996); or by expert ratings of a particular solution, suggestion, or product introduced by individuals (Shalley, 1995). At the team level, the innovativeness of teams, regular and ad hoc workgroups, and business units is the focus of attention. Thus, the total number of suggestions, new products, or patents developed by a team of individuals are variously used as criterion measures (Cardinal, 2001; Jung, Chow, \& Wu, 2003). Furthermore, teamlevel innovation is frequently assessed by self or supervisor ratings of team innovativeness (Agrell \& Gustafson, 1994; Kratzer, Leenders, \& Van Engelen, 2004).

Measurement levels can be differentiated on both the criterion and the predictor side. Typically, predictor and criterion measurement levels concur: Most studies investigating individual-level antecedents, like intelligence or personality characteristics, are interested in their impact on individual innovation (we term this Type 1 designs). Likewise most studies investigating team-level antecedents are interested in their impact on team innovation (Type 2 designs). However, a considerable number of studies examine individual perceptions of team-level variables, especially team processes and their influence on individual innovation (Type 3 designs). The issue of measurement levels is closely linked to the question of the level at which data are treated statistically. Studies pertaining to Type 1 are most straightforward; individual responses are used to assess the relationship between individual antecedent variables and individual innovation. Type 2 research designs typically aggregate individual responses on predictor measures to the team level (e.g., Brodbeck \& Maier, 2001; PirolaMerlo \& Mann, 2004; West \& Anderson, 1996) and link them to innovation assessed at the same level, using number of teams as sample size. Studies falling into a Type 3 design use individual perceptions of team processes as the unit of analysis (e.g., Axtell et al., 2000; Baer \& Oldham, 2006; Farmer, Tierney, \& KungMcIntyre, 2003; Scott \& Bruce, 1994) and link them to individual innovation, using number of respondents as sample size. Whereas Type 1 designs do not fall within the scope of the present metaanalysis, studies of Type 2 as well as of Type 3 are included, because both examine team-level antecedents of innovation. Neither can be considered correct or incorrect, but we should be clear about their different focuses: Studies of Type 2 are interested in shared perceptions of team variables and their impact on team innovativeness, whereas studies of Type 3 are interested in individual perceptions of team variables and their impact on individual innovativeness. It is therefore important to recognize and test these differences in levels of analysis because we cannot assume that team characteristics have the same influence on individual innovation as on team innovation. Analyzing the relationship between cohesion and general team performance, Gully, Devine, and Whitney (1995) demonstrated that the relationship was higher if both constructs were measured at the team level. Yet differences in measurement levels and their influence on predictor-criterion relationships have not been systematically addressed in innovation research so far. We expect that the variance in effect sizes is, to a considerable extent, due to differences in measurement levels in original studies and that therefore measurement level will consid- erably moderate the relationship between team-level antecedents and innovation.

\section{Measurement Method}

Criteria used to assess innovation vary also with respect to measurement method. A lot of studies use self-ratings of innovation (Axtell et al., 2000; Caldwell \& O'Reilly, 2003; Clegg, Unsworth, Epitropaki, \& Parker, 2002; Ohly, Sonnentag, \& Pluntke, 2006) or independent ratings of innovation, which encompass supervisor ratings (Oldham \& Cummings, 1996; West \& Anderson, 1996), peer ratings (Amabile et al., 2002), and ratings by subject matter experts (Shalley, 1995; Shalley \& Perry-Smith, 2001). Other studies rely on objective criteria to assess innovation at work, counting the number of contributions to a suggestion system or the number of patents or new products (Cardinal, 2001; Frese, Teng, \& Wijnen, 1999; Pirola-Merlo \& Mann, 2004). Typically, these different measurement methods display only moderate correlations. More important, the relationships between antecedent variables and innovation differ substantially depending on the measurement method (Pirola-Merlo \& Mann, 2004; Tierney, Farmer, \& Graen, 1999; West \& Anderson, 1996). Therefore, it is important to systematically assess differences in predictorcriterion correlations due to differences in the measurement method used. We expect higher correlations between team process variables with self-ratings of innovation compared with independent ratings or objective indicators of innovation. Team process variables are almost always assessed via self-report. If the same individuals report on team processes as well as on their team's or their own innovative performance, correlations are likely to be higher, because not only is the same measurement method used (questionnaires) but also the same information source (team members). Self-reports are a source of common method bias that inflates the covariation between predictor and criterion. This artifactual inflation might be attributed to, for example, the respondents' tendency to maintain consistency in their responses, implicit theories respondents hold about relationships, socially desirable responding, and leniency biases (for a detailed discussion, see Podsakoff, MacKenzie, Lee, \& Podsakoff, 2003). Thus, asking team members about their communication processes, their vision, and their norms for innovation might influence their ratings of the team's or their own innovativeness. This effect is, of course, absent if different sources are used to assess predictor and criterion variables, and so our second examination of moderator effects was to test for dependent variable measurement differences.

\section{Method}

\section{Literature Search and Coding of Studies}

We conducted an extensive literature search, both computerbased and manual, to identify studies published before or during March 2007. To cover the literature on team-level antecedents of innovation as exhaustively as possible and prevent any bias in the inclusion of studies, we adopted a series of search strategies. First, the PsychInfo, Social Sciences Citation Index, and ABI/Inform databases were searched to identify studies on the relationship between any structural or process variable at the team level and work-related innovation or creativity. Several keywords were used 
for the computer-based literature search (e.g., creativity, creative, innovation, and innovative). Second, a manual article-by-article search was carried out in a number of top-tier journals (e.g., Academy of Management Journal, Journal of Applied Psychology, Journal of Organizational Behavior). Third, the reference sections of several narrative reviews (e.g., Anderson et al., 2004; Anderson \& King, 1993; Mumford \& Licuanan, 2004; Mumford, Scott, Gaddis, \& Strange, 2002; Shalley \& Gilson, 2004; Shalley et al., 2004; West, 2002) were reviewed to identify articles not covered in our computer-based search. Fourth, efforts were undertaken to identify and get access to studies conducted in non-Englishspeaking countries and published in journals using languages other than English. Several studies published in, for instance, Dutch and German journals were therefore included in the database. By means of these search strategies, a preliminary database of over 500 articles was established for further inspection.

According to our definition of innovation, the following inclusion criteria were developed: Studies were included if they dealt with the relationship between team-level variables and work-related innovation or creativity. As we were interested in identifying antecedents of innovation in organizations, only studies with a work-related operationalization of innovation were included in the database. Different measurement methods of innovation were considered, such as selfreport, peer report, supervisor report, and objective measures of innovation. Furthermore, studies were only included if they reported effect size indices that are convertible to correlation coefficients. The relationships reported in the original studies were classified into predefined categories of team-level characteristics (cf. Tables 1 and 2). After we applied these decision rules, the final database consisted of 91 articles reporting effect sizes for 104 independent studies or samples, with an overall $N$ of 50,096.

In accordance with Hunter and Schmidt (2004), each sample contributed only one correlation to the meta-analysis. If studies reported conceptual replications (e.g., self-ratings and supervisor ratings of innovative work behavior or idea generation and implementation as two subfacets of innovation), composite correlations were computed for the overall analysis. Reliabilities of these composite measures were computed using Mosier's (1943) formula. If necessary, conceptual replications were coded independently in addition to the composite correlation to allow moderator analyses (e.g., self-ratings of innovation vs. independent ratings of innovation and objective criteria).

Overall, 284 predictor-criterion relationships were coded by Ute R. Hülsheger regarding all relevant study characteristics. Additionally, $30 \%$ of these were coded by a second trained coder. Interrater agreement was assessed by intraclass coefficients, $\operatorname{ICC}(2,1)$, for sample size (1.0), predictor-criterion relationship (.995), predictor reliability (1.0), and criterion reliability (.898). For predictor category (.962), measurement method of innovation (.797), and measurement level (.968), we computed Cohen's kappa. Consensus concerning all prior disagreements was reached by discussion.

\section{Meta-Analytic Procedure}

To conduct the meta-analysis, we followed the procedures described by Hunter and Schmidt (2004). Accordingly, observed

Table 1

Meta-Analysis of the Relationships Between Input Variables and Innovation: Overall Analyses and Moderator Analyses by Measurement Level and Measurement Method

\begin{tabular}{|c|c|c|c|c|c|c|c|c|c|}
\hline $\begin{array}{c}\text { Team-level } \\
\text { characteristics }\end{array}$ & $k$ & $N$ & $r$ & $S^{2} r$ & $\rho$ & $S D_{\rho}$ & $\% \mathrm{VE}$ & $80 \% \mathrm{CV}$ & $95 \% \mathrm{CI}$ \\
\hline Team size & 28 & 1,835 & .158 & .048 & .172 & .213 & 29.5 & $-.101, .444$ & $.078, .266$ \\
\hline Individual innovation & 2 & 564 & -.095 & .011 & -.101 & .090 & 32.7 & $-.217, .014$ & $-.253, .051$ \\
\hline Team innovation & 24 & 1,359 & .228 & .047 & .259 & .207 & 33.6 & $-.006, .524$ & $.157, .360$ \\
\hline Self-rating & 7 & 577 & -.016 & .005 & -.017 & 0 & 100.0 & $-.017,-.017$ & $-.071, .037$ \\
\hline Independent rating & 22 & 1,276 & .208 & .047 & .236 & .214 & 32.5 & $-.038, .509$ & $.127, .345$ \\
\hline Team longevity & 10 & 4,262 & .019 & .056 & .020 & .257 & 4.2 & $-.309, .349$ & $-.143, .183$ \\
\hline Team innovation & 9 & 549 & -.052 & .077 & -.062 & .272 & 21.8 & $-.411, .287$ & $-.263, .139$ \\
\hline Self-rating & 4 & 1,025 & -.335 & .016 & -.366 & .119 & 20.5 & $-.519,-.213$ & $-.497,-.235$ \\
\hline Independent rating & 7 & 3,480 & .119 & .018 & .133 & .142 & 10.8 & $-.049, .314$ & $.022, .244$ \\
\hline Job-relevant diversity & 15 & 5,243 & .139 & .071 & .155 & .293 & 3.9 & $-.220, .530$ & $.004, .306$ \\
\hline Team innovation & 10 & 598 & .212 & .083 & .240 & .285 & 19.2 & $-.125, .605$ & $.044, .436$ \\
\hline Self-rating & 6 & 1,379 & -.009 & .030 & -.010 & .173 & 14.4 & $-.231, .212$ & $-.160, .140$ \\
\hline Independent rating & 10 & 4,371 & .140 & .066 & .159 & .288 & 3.3 & $-.209, .528$ & $.016, .302$ \\
\hline Background diversity & 8 & 3,634 & -.117 & .056 & -.133 & .262 & 3.8 & $-.468, .203$ & $-.318, .052$ \\
\hline Team innovation & 7 & 490 & -.089 & .061 & -.101 & .245 & 23.5 & $-.414, .213$ & $-.308, .106$ \\
\hline Independent rating & 7 & 3,484 & -.112 & .058 & -.127 & .268 & 3.4 & $-.470, .215$ & $-.329, .075$ \\
\hline Task interdependence & 4 & 977 & .034 & .023 & .040 & .182 & 17.7 & $-.193, .274$ & $-.157, .237$ \\
\hline Team innovation & 4 & 130 & .023 & .022 & .025 & 0 & 100.0 & $.025, .025$ & $-.166, .216$ \\
\hline Independent rating & 4 & 977 & .034 & .023 & .040 & .182 & 17.7 & $-.193, .274$ & $-.157, .237$ \\
\hline Goal interdependence & 5 & 1,174 & .208 & .021 & .276 & .161 & 20.4 & $.070, .482$ & $.118, .434$ \\
\hline Team innovation & 5 & 222 & .172 & .016 & .237 & 0 & 100.0 & $.237, .237$ & $.097, .377$ \\
\hline Independent rating & 5 & 1,174 & .208 & .021 & .276 & .161 & 20.4 & $.070, .482$ & $.118, .434$ \\
\hline
\end{tabular}

Note. $\quad k=$ number of studies; $N=$ total sample size for all studies combined, based on number of individual participants for all analyses except for team innovation, where it is based on number of teams; $r=$ sample size weighted average observed correlation; $S^{2} r=$ sample size weighted observed variance of correlations; $\rho=$ average corrected correlation (corrected for sampling and measurement error in the predictor and criterion); $S D_{\rho}=$ standard deviation of $\rho ; \% \mathrm{VE}=$ variance accounted for by artifacts; $80 \% \mathrm{CV}=10 \%$ lower and $90 \%$ upper limits of $80 \%$ credibility interval; $95 \% \mathrm{CI}=2.5 \%$ lower and $97.5 \%$ upper limits of $95 \%$ confidence interval. 
Table 2

Meta-Analysis of the Relationships Between Process Variables and Innovation: Overall Analyses and Moderator Analyses by Measurement Level and Measurement Method

\begin{tabular}{|c|c|c|c|c|c|c|c|c|c|}
\hline $\begin{array}{c}\text { Team-level } \\
\text { characteristics }\end{array}$ & $k$ & $N$ & $r$ & $S^{2} r$ & $\rho$ & $S D_{\rho}$ & $\% \mathrm{VE}$ & $80 \% \mathrm{CV}$ & $95 \% \mathrm{CI}$ \\
\hline Support for innovation & 39 & 15,604 & .390 & .027 & .470 & .193 & 6.6 & $.222, .717$ & $.407, .533$ \\
\hline Individual innovation & 17 & 3,583 & .219 & .019 & .261 & .140 & 23.5 & $.082, .441$ & $.185, .337$ \\
\hline Team innovation & 10 & 367 & .488 & .022 & .581 & .069 & 82.9 & $.492, .670$ & $.477, .685$ \\
\hline Self-rating & 22 & 5,376 & .385 & .045 & .455 & .249 & 6.4 & $.136, .773$ & $.348, .562$ \\
\hline Independent rating & 20 & 11,147 & .396 & .019 & .482 & .163 & 6.7 & $.274, .691$ & $.408, .556$ \\
\hline Objective measures & 2 & 279 & .343 & .005 & .371 & 0 & 100.0 & $.371, .371$ & $.262, .480$ \\
\hline Participative safety & 37 & 23,146 & .119 & .029 & .148 & .204 & 5.4 & $-.113, .410$ & $.080, .216$ \\
\hline Individual innovation & 17 & 7,000 & .126 & .008 & .165 & .091 & 31.6 & $.049, .281$ & $.113, .217$ \\
\hline Team innovation & 15 & 2,168 & .121 & .029 & .150 & .177 & 24.9 & $-.076, .376$ & $.047, .253$ \\
\hline Self-rating & 20 & 8,896 & .279 & .045 & .341 & .241 & 4.5 & $.033, .650$ & $.233, .449$ \\
\hline Independent rating & 22 & 15,601 & .078 & .017 & .096 & .155 & 8.2 & $-.102, .295$ & $.028, .164$ \\
\hline Objective measures & 3 & 12,084 & .085 & .006 & .092 & .084 & 3.9 & $-.016, .200$ & $-.005, .189$ \\
\hline Vision & 17 & 4,638 & .412 & .051 & .493 & .284 & 4.4 & $.130, .856$ & $.355, .631$ \\
\hline Individual innovation & 3 & 906 & .131 & .009 & .150 & .094 & 32.6 & $.029, .270$ & $.020, .280$ \\
\hline Team innovation & 11 & 457 & .377 & .049 & .435 & .238 & 31.8 & $.130, .739$ & $.265, .605$ \\
\hline Self-rating & 12 & 3,847 & .451 & .051 & .527 & .272 & 3.6 & $.179, .875$ & $.370, .684$ \\
\hline Independent rating & 10 & 2,292 & .323 & .032 & .392 & .213 & 10.4 & $.120, .665$ & $.253, .531$ \\
\hline Objective measures & 2 & 418 & .170 & .018 & .179 & .121 & 25.7 & $.024, .333$ & $-.015, .373$ \\
\hline Task orientation & 18 & 4,688 & .345 & .061 & .415 & .285 & 5.0 & $.050, .780$ & $.280, .550$ \\
\hline Individual innovation & 4 & 1,009 & .055 & .013 & .067 & .113 & 31.5 & $-.078, .212$ & $-.067, .201$ \\
\hline Team innovation & 11 & 496 & .382 & .055 & .453 & .231 & 30.7 & $.157, .749$ & $.289, .617$ \\
\hline Self-rating & 8 & 1,927 & .403 & .076 & .485 & .314 & 4.0 & $.083, .886$ & $.263, .707$ \\
\hline Independent rating & 13 & 3,490 & .354 & .055 & .435 & .270 & 5.5 & $.089, .781$ & $.284, .586$ \\
\hline Objective measures & 2 & 418 & .268 & 0 & .273 & 0 & 100.0 & $.273, .273$ & $.252, .294$ \\
\hline Cohesion & 11 & 3,588 & .252 & .035 & .307 & .208 & 8.3 & $.042, .573$ & $.179, .435$ \\
\hline Individual innovation & 4 & 1,188 & .266 & .016 & .331 & .132 & 20.3 & $.162, .500$ & $.186, .476$ \\
\hline Team innovation & 5 & 336 & .208 & .016 & .250 & 0 & 100.0 & $.250, .250$ & $.129, .371$ \\
\hline Self-rating & 5 & 1,495 & .460 & .017 & .513 & .150 & 10.5 & $.321, .706$ & $.374, .652$ \\
\hline Independent rating & 8 & 2,785 & .157 & .010 & .192 & .105 & 27.5 & $.058, .327$ & $.107, .277$ \\
\hline Internal communication & 13 & 3,356 & .289 & .041 & .358 & .230 & 8.5 & $.064, .652$ & $.228, .488$ \\
\hline Individual innovation & 2 & 228 & .300 & .005 & .369 & 0 & 100.0 & $.369, .369$ & $.251, .487$ \\
\hline Team innovation & 7 & 433 & .264 & .037 & .327 & .172 & 41.6 & $.106, .548$ & $.160, .494$ \\
\hline Self-rating & 6 & 1,404 & .517 & .015 & .590 & .151 & 11.9 & $.398, .783$ & $.462, .718$ \\
\hline Independent rating & 9 & 2,848 & .210 & .020 & .261 & .162 & 14.5 & $.054, .467$ & $.147, .375$ \\
\hline External communication & 7 & 2,719 & .381 & .012 & .475 & .116 & 17.7 & $.326, .624$ & $.380, .570$ \\
\hline Individual innovation & 2 & 457 & .336 & .015 & .418 & .126 & 25.0 & $.257, .579$ & $.217, .619$ \\
\hline Team innovation & 4 & 200 & .351 & .013 & .450 & 0 & 100.0 & $.450, .450$. & $.310, .590$ \\
\hline Self-rating & 2 & 1,463 & .460 & .001 & .558 & .012 & 89.5 & $.542, .573$ & $.507, .609$ \\
\hline Independent rating & 5 & 1,256 & .289 & .009 & .361 & .100 & 34.5 & $.233, .489$ & $.252, .470$ \\
\hline Task conflict & 13 & 2,841 & .055 & .083 & .067 & .360 & 5.5 & $-.394, .527$ & $-.134, .268$ \\
\hline Individual innovation & 2 & 636 & -.067 & .165 & -.087 & .510 & 1.9 & $-.740, .567$ & $-.800, .627$ \\
\hline Team innovation & 9 & 302 & -.019 & .058 & -.031 & .209 & 53.5 & $-.299, .236$ & $-.023, .170$ \\
\hline Self-rating & 5 & 1,148 & -.111 & .115 & -.140 & .423 & 3.7 & $-.681, .402$ & $-.518, .238$ \\
\hline Independent rating & 8 & 1,693 & .030 & .053 & .034 & .283 & 8.9 & $-.329, .397$ & $-.172, .240$ \\
\hline Relationship conflict & 6 & 1,304 & -.073 & .026 & -.092 & .182 & 17.6 & $-.325, .141$ & $-.252, .068$ \\
\hline Team innovation & 2 & 70 & .021 & .012 & .026 & 0 & 100.0 & $.026, .026$ & $-.162, .214$ \\
\hline Self-rating & 4 & 775 & -.136 & .026 & -.168 & .181 & 19.0 & $-.399, .063$ & $-.365, .029$ \\
\hline Independent rating & 2 & 529 & .018 & .012 & .022 & .111 & 32.6 & $-.120, .164$ & $-.165, .209$ \\
\hline
\end{tabular}

Note. $\quad k=$ number of studies; $N=$ total sample size for all studies combined, based on number of individual participants for all analyses except for team innovation, where it is based on number of teams; $r=$ sample size weighted average observed correlation; $S^{2} r=$ sample size weighted observed variance of correlations; $\rho=$ average corrected correlation (corrected for sampling and measurement error in the predictor and criterion); $S D_{\rho}=$ standard deviation of $\rho ; \% \mathrm{VE}=$ variance accounted for by artifacts; $80 \% \mathrm{CV}=10 \%$ lower and $90 \%$ upper limits of $80 \%$ credibility interval; $95 \% \mathrm{CI}=2.5 \%$ lower and $97.5 \%$ upper limits of $95 \%$ confidence interval.

correlations were corrected for sampling error and measurement error in both the predictor and criterion. In doing so we had to choose between two types of meta-analyses: (a) correcting each study individually for artifacts and (b) using artifact distributions. For two reasons, we applied the first strategy: First, information on predictor and criterion reliability was present in the majority of the studies. The second and more important reason for individual artifact corrections was that the studies comprised three different types of criteria, which need to be treated differently. The first type describes self-ratings of innovation, a case in which internal consistency reliability values are adopted for correction. Type 2 consists of independent ratings of innovation (i.e., peer or supervisor 
ratings), a case in which interrater reliability is the suitable reliability coefficient. Type 2 comprises objective measures of performance (e.g., number of suggestions to a suggestion system, number of patents), which can be assumed to be measured without error variance, and hence no correction for measurement error was made. Thus, following this distinction, studies were corrected individually for artifacts, and the respective reliability coefficients were adopted for the correction of measurement error in the criterion. Unreported reliability coefficients were substituted with the average reliability reported for the respective criterion type in the overall sample: .85 for self-ratings (internal consistency) and .78 for independent ratings (interrater reliability). In the case of predictor reliability, most of the original studies reported internal consistency reliabilities of the measures. Therefore, we used the corresponding values to correct the observed correlations for attenuation. Again, if reliability was not reported in the original study, the average reliability of this particular measure reported in other studies was substituted for the missing value. For objective predictor measures (e.g., team size and team longevity), no corrections for unreliability were made, as they can be assumed to be perfectly measured.

With respect to corrections for sampling error and sample size, weighted mean correlations were computed. However, some studies analyzed the relationship between team-level predictors and innovation on the basis of the number of individual participants, others on the number of teams (cf. discussion of measurement level issues in the introduction). Mixing these two types of sample sizes (number of participants and number of teams) in the metaanalysis would produce incorrect results, because studies based on number of teams would be weighted less and have lower impact on the overall results than studies based on the number of individual participants. Therefore, for the overall analyses, the individual number of participants was looked up in primary studies and used for meta-analytic corrections in those studies originally reporting the number of teams as sample size. However, in the moderator analysis by measurement level we differentiated between studies measuring innovation at the individual and at the team level. Here, for the subgroup analyses, number of participants was used as total sample size for individual innovation, whereas number of teams was used at the team level.

Apart from corrected correlations and their standard deviation, we report $80 \%$ credibility as well as $95 \%$ confidence intervals, because both convey important but different information (Hunter \& Schmidt, 2004; Judge, Colbert, \& Ilies, 2004; Whitener, 1990). Credibility intervals indicate whether the corrected correlation can be generalized or whether it is situation specific (i.e., whether it varies between different organizational settings). Thus, this interval conveys information on the variability of individual correlations. From the width of the credibility interval, it can be inferred whether moderators are operating. In the case of both positive and negative mean corrected correlations $(\rho)$, generalizability can be inferred if the credibility interval does not include zero. In contrast, the confidence interval is not about the variability of individual correlations, but it informs us about the accuracy of the mean corrected correlation and can be used as a significance test. If the confidence interval does not include zero, the mean corrected correlation is considered to be significant. As we computed 95\% confidence intervals, a confidence interval that does not include zero indicates that the corrected correlation is significant at a level of $p<.05$ (two-tailed). For moderator analyses, nonoverlapping confidence intervals indicate that mean corrected correlations are significantly different from each other. Nonoverlapping confidence intervals are a sufficient but not a necessary condition. Thus, even if confidence intervals overlap, values can still be significantly different from one another (for interpretation of confidence intervals, see Cumming \& Finch, 2005).

To detect whether moderating influences might exist, we thus inspected the credibility intervals. In addition, we applied the $75 \%$ rule of thumb suggested by Hunter and Schmidt (2004), according to which a search for moderators is warranted if less than $75 \%$ of the observed variance in observed correlations can be explained by artifacts.

\section{Results}

\section{Overall Relationships Between Team-Level Characteristics and Innovation}

Regarding input variables (see Table 1), we hypothesized positive relationships between job-relevant diversity (H1a), task and goal interdependence ( $\mathrm{H} 2 \mathrm{a}, \mathrm{H} 2 \mathrm{~b})$, team size $(\mathrm{H} 3)$, and innovation, and a negative relationship between background diversity (H1b), team longevity (H4), and innovation. Small (Cohen, 1988) but significant positive mean corrected correlations emerged for team size $(\rho=.172)$, job-relevant diversity $(\rho=.155)$, and goal interdependence $(\rho=.276)$. Mean corrected correlations were insignificant for team longevity $(\rho=.020)$ and task interdependence $(\rho=.040)$, whereas background diversity displayed a small negative, yet nonsignificant, relationship with innovation $(\rho=$ -.133 ). Except for goal interdependence, all credibility intervals included zero. Consequently, relationships varied considerably between original studies that included negative and positive relationships with innovation, indicating that validity does not generalize across different settings and situations. Taking a conservative approach, we thus cannot unreservedly conclude that our Hypotheses 1 to 4 have been supported. Although the corrected correlations point in the hypothesized direction, effect sizes are small and do not display validity generalization. An exception is goal interdependence $(\mathrm{H} 2 \mathrm{~b})$, which displayed a significant positive relationship with innovation and for which validity generalization was confirmed.

With regard to process variables, we hypothesized positive corrected correlations with innovation for vision (H5), participative safety (H6), support for innovation (H7), task orientation (H8), cohesion (H9), internal and external communication (H10a, $\mathrm{H} 10 \mathrm{~b}$ ), and task conflict (H11a), and a negative correlation for relationship conflict (H11b). Results for team processes are indicated in Table 2. Overall, team process variables were strongly linked to overall measures of innovation. Strongest corrected correlations emerged for vision $(\rho=.493)$, external communication $(\rho=.475)$, support for innovation $(\rho=.470)$, and task orientation $(\rho=.415)$. Furthermore, internal communication $(\rho=.358)$ as well as cohesion $(\rho=.307)$ displayed considerable relationships with innovation. Those correlations can be evaluated as medium to strong effects (Cohen, 1988) and thus support Hypotheses 5, 7, 8, 9, and 10. Confidence as well as credibility intervals excluded zero, showing that the corrected correlations were significant and that the relationships were generalizable. In contrast, participative 
safety displayed only a weak, nongeneralizable positive correlation $(\rho=.148)$ with innovation. Mean corrected correlations for task and relationship conflict were low $(\rho=.067$ and $\rho=-.092$, respectively). Confidence as well as credibility intervals included zero, indicating that mean corrected correlations were not significant and that correlations showed considerable variability in magnitude and direction. Hypotheses 6 and 11 thus could not be supported.

Overall, percentages of variance accounted for by artifacts were extremely low, ranging between $3.8 \%$ and $29.5 \%$; they came nowhere near $75 \%$, which according to Hunter and Schmidt (2004)'s rule of thumb is the critical value indicative of potential moderator effects. Therefore, we proceeded to investigate whether measurement level and measurement method moderate the relationships between team characteristics and innovation.

\section{Moderator Analyses}

Measurement level. To conduct the moderator analysis by measurement level, we coded the studies as to whether they pertained to the individual or the team level of analysis. Studies measuring team structural variables and individual perceptions of team processes and linking them to measures of individual innovativeness fell into the first category, individual innovation (Type 3). Studies measuring team processes and structure as well as innovation at the level of the work team were coded at the team level (Type 2). Only studies that could unequivocally be attributed to one of these two categories were included in this subgroup analysis. Thus, only studies aggregating individual perceptions of team variables to the team level at the predictor side and measuring team innovation at the criterion side were included. It is important to note that subgroup analyses of individual innovation are based on number of participants as sample size, and subgroup analyses of team innovation are based on number of work teams as sample size.

Results confirm that measurement level moderates the relationship between team input and process variables on the one hand and innovation on the other hand. Correlations with innovation were considerably stronger if innovation was measured at the team level compared with the individual level. In the case of support for innovation, task orientation, and vision, these differences were sizeable in magnitude and confidence intervals were not overlapping, or were only marginally so. However, in the case of participative safety, cohesion, internal communication, and task conflict, relationships with individual and team innovation were comparable, and confidence intervals overlapped considerably. For all team process variables, the percentage of variance accounted for by artifacts was notably higher in the subgroups compared with the overall groups. This confirms that measurement level does indeed moderate the relationship between team processes and innovation. For input variables, a differentiation between individual innovation and team innovation could only be conducted for team size, due to the limited number of primary studies. This moderator analysis revealed that team size displayed a positive relationship with team innovation $(\rho=.259)$ and a slightly negative with individual innovation $(\rho=-.101)$. Although no distinction between team and individual innovation could be made for the other input variables, the results of the subgroup analyses for team innovation can be compared with the overall analyses (Table 1). In the case of job-relevant diversity, this comparison reveals a higher relationship between job-relevant diversity and innovation $(\rho=.240)$ if we include in the analysis only those studies that aggregate data appropriately at the team level of analysis. This finding further supports Hypothesis 1a, suggesting an overall positive relationship between job-relevant diversity and innovation.

Measurement method. Furthermore, we tested whether measurement method moderates the relationship between team input and process variables and innovation. For all process dimensions except for support for innovation, predictor-criterion relations were considerably stronger if self-report measures had been used in contrast to independent ratings or objective criteria of innovation. With regard to objective criteria of innovation, it is important to note that the number of studies $(k)$ included in this category is relatively low. Consequently, results should be interpreted with some caution. In the case of participative safety, cohesion, and internal and external communication, the differences were substantial and significant. Interesting findings emerged for the input variables, team size, longevity, and job-relevant diversity. Selfratings were negatively related to innovation, whereas independent ratings had a positive sign.

\section{Discussion}

This article reports a quantitative summary of three decades of primary studies into direct relations between team characteristics and team processes and innovation using robust procedures within meta-analysis. Two classes of antecedent variables-input and process variables-and methodological moderator variables were considered. Key findings from this quantitative summary are presented in Table 3 on each of the 11 hypotheses specified earlier in this article. In overview, three centrally important findings emerge. First, team process variables display substantial and generalizable relationships with innovation. External and internal communication, vision, support for innovation, task orientation, and cohesion are especially conducive to innovation $-\rho$ s are in the range of .3 to .5 , and are thus substantial mean effect sizes. Second, team input variables display only relatively small and variable relationships with innovation $-\rho$ s are in the range of only .1 to .2 or lower. Nevertheless, we can conclude that goal interdependence, jobrelevant diversity, and team size are somewhat conducive to team innovation (with $\rho$ s of around .2). Third, these main relationships are moderated by measurement level and measurement method. Relationships between team process variables and innovation are stronger for team than individual innovation. Further, relationships are considerably stronger if self-ratings of innovation are employed, compared with independent ratings or objective measures of innovation. We now consider the implications of these findings for our understanding of innovation predictors within work teams, for future directions for team-level innovation research, and for pragmatic attempts to facilitate creativity and innovation in work teams.

\section{Team Input Variables: Team Composition and Structure}

Goal interdependence was found to be the most influential team structural variable for innovation in the workplace $(\rho=.276)$. This finding underlines the importance of common team goals, and it is in line with our finding on the strong link between the team 
Table 3

Overview of Hypotheses and Key Meta-Analytic Findings

\begin{tabular}{|c|c|c|c|c|c|}
\hline Variable & Hypothesis & $\begin{array}{l}\text { Hypothesized direction } \\
\text { of relationship with } \\
\text { innovation }\end{array}$ & $\begin{array}{l}\text { Mean overall corrected } \\
\text { correlation with } \\
\text { innovation }(\rho)\end{array}$ & $\begin{array}{l}\text { Significance } \\
\text { of } \rho\end{array}$ & $\begin{array}{c}\text { Validity } \\
\text { generalization }\end{array}$ \\
\hline \multicolumn{6}{|c|}{ Input variables: Team composition and structure } \\
\hline Job-relevant diversity & $\mathrm{H} 1 \mathrm{a}$ & + & .155 & yes & no \\
\hline Background diversity & $\mathrm{H} 1 \mathrm{~b}$ & - & -.133 & no & no \\
\hline Task interdependence & $\mathrm{H} 2 \mathrm{a}$ & + & .040 & no & no \\
\hline Goal interdependence & $\mathrm{H} 2 \mathrm{~b}$ & + & .276 & yes & yes \\
\hline Team size & $\mathrm{H} 3$ & + & .172 & yes & no \\
\hline Team longevity & $\mathrm{H} 4$ & - & .020 & no & no \\
\hline \multicolumn{6}{|l|}{ Team process variables } \\
\hline Vision & H5 & + & .493 & yes & yes \\
\hline Participative safety & H6 & + & .148 & yes & no \\
\hline Support for innovation & $\mathrm{H} 7$ & + & .470 & yes & yes \\
\hline Task orientation & $\mathrm{H} 8$ & + & .415 & yes & yes \\
\hline Cohesion & H9 & + & .307 & yes & yes \\
\hline Internal communication & H10a & + & .358 & yes & yes \\
\hline External communication & $\mathrm{H} 10 \mathrm{~b}$ & + & .475 & yes & yes \\
\hline Task conflict & H11a & + & .067 & no & no \\
\hline Relationship conflict & $\mathrm{H} 11 \mathrm{~b}$ & - & -.092 & no & no \\
\hline \multicolumn{6}{|l|}{ Moderating influences } \\
\hline Measurement level & \multicolumn{5}{|c|}{ Team innovation vs. individual innovation } \\
\hline Measurement method & \multicolumn{5}{|c|}{ Self-ratings, independent ratings vs. objective measures } \\
\hline
\end{tabular}

Note. Significance of $\rho$ is inferred if confidence intervals do not include zero; validity generalization is inferred if credibility intervals do not include zero. $\mathrm{H}=$ hypothesis.

process dimension of vision, describing the commitment of team members to superordinate team goals, and innovation (see also West, 2002). The way in which team goals are designed influences the interaction among team members-whether they cooperate or compete, help or hinder each other (Stanne, Johnson, \& Johnson, 1999). Goal interdependence can be achieved by providing collective rather than individual goals, providing group feedback, and linking performance evaluations and rewards to those team goals (Van der Vegt \& Van de Vliert, 2002; Wageman, 1995). The positive influence of goal interdependence on innovation might be due to motivational effects and enhanced communication and cooperation within the team (Campion, Papper, \& Medsker, 1996). In contrast, task interdependence is neither consistently nor significantly related to innovation. Nevertheless, we should not discard this concept prematurely. As only a few studies have investigated the role of interdependence on innovative work behavior, more research is certainly warranted to clarify the underlying processes of these relationships. Furthermore, task and goal interdependence might exert an interactive effect on team innovation similar to the effect that has been shown for team performance (Saavedra et al., 1993; Wageman, 1995).

With respect to diversity, a slight negative relationship between background diversity and innovation emerged $(\rho=-.133)$. In contrast, job-relevant diversity displayed a slight positive relationship with innovation in the overall analysis $(\rho=.155)$, substantiating the contention that diversity with regard to job-related attributes has a greater impact on performance than diversity with regard to less job-related attributes (Pelled et al., 1999). The difference between job-relevant and background diversity became even more clear in the moderator analysis by measurement level: If we considered only those studies that adhered to rigorous team-level designs, job-relevant diversity yielded a moderate cor- rected mean correlation of .24 . Thus, our findings confirm the importance of differentiating between job-relevant and background diversity (Pelled, 1996; Pelled et al., 1999) for understanding the link between diversity and innovation. The two kinds of diversity displayed differential relationships with the innovative performance of teams, not only in size but also in the direction of effects. These findings do not concur with the findings of previous meta-analyses that investigated the link between more or less job-related diversity and general team performance (Stewart, 2006; Webber \& Donahue, 2001), thus vindicating our decision to hypothesize innovation-specific effects for the present meta-analytic effort. In both meta-analyses on general team performance, the two types of diversity did not display differential relationships with performance, and the relationships between both types of diversity with performance were about zero. This exemplifies the need to differentiate carefully between different aspects of team performance: Whereas both types of diversity do not seem to play an important role for general team performance, job-relevant diversity does seem to be conducive to innovation, especially at the team level of analysis. However, remaining gaps in our understanding of the link between job-relevant diversity and innovation are only too evident: Is diversity a proximal or a more distal predictor of innovation? Is the relationship truly linear or possibly curvilinear? What is the role of potential moderators like team longevity or cohesion? All of these issues warrant further research attention. Possibly job-relevant diversity is more strongly related to innovation in teams with a higher team tenure, which allows them to agree on team norms, align their working styles, and overcome coordination and cooperation problems. In a similar vein, there might be a stronger positive link between job-relevant diversity and innovation under conditions of high cohesion and the existence of shared mental models (Bledow et al., 2009; Kozlowski \& 
Bell, 2003). Furthermore, leadership could play an important role in deploying the potential of job-relevant diversity to stir up innovation by sensitizing team members to their different kinds of knowledge, skills, and abilities, and by helping them to value and use their different viewpoints and engage in elaboration and integration of opposing viewpoints.

With regard to team size and team longevity, findings of the overall analysis were inconclusive: Corrected mean correlations were low ( $\rho=.172$ and .020 ), and the credibility interval included zero, indicating nongeneralizability of these effect sizes. However, moderator analyses helped to resolve and explain these inconsistent findings present in primary studies. For team size, the moderator analysis by measurement level revealed that team size displayed a positive significant relationship with team innovation but a slight negative relationship with individual innovation. These findings match arguments presented around team size: Tendencies to engage in social loafing and free-riding are supposed to be elevated in larger teams (Gooding \& Wagner, 1985). If team members engage in social loafing, they reduce their individual effort, which should thus lead to reduced levels of individual innovation. On the other hand, an increased team size with its associated variety of relevant knowledge, skills, and abilities has been argued to be particularly important for teams that have to fulfill difficult tasks (Stewart, 2006). Developing new products, suggesting new processes and procedures, and implementing them at work can be considered a complex team task. Consequently, larger team sizes and the associated multitude of skills and knowledge benefit innovation at the team level. Team longevity displayed a mean corrected correlation of near zero $(\rho=.020)$ and a large credibility and confidence interval in the overall analysis. However, our moderator analysis revealed that the variability of effect sizes is to a large extent due to differences in measurement methods: Although the corrected correlation with innovation is negative and significant in the case of self-ratings $(\rho=-.366)$, it is positive ( $\rho=.133$ ) in the case of independent ratings of innovation. Negative relationships between team longevity and innovation might thus be partly attributed to common method or perception bias. Obviously, team longevity not only has the suggested negative effects on innovation but also might have positive consequences. Team longevity could contribute to team cohesiveness and thereby to innovation (King \& Anderson, 1990).

\section{Team Processes}

Overall, it can be concluded that team process variables display stronger links with innovation than input variables. Vision $(\rho=$ .493), external communication ( $\rho=.475)$, support for innovation $(\rho=.470)$, task orientation $(\rho=.415)$, and internal communication $(\rho=.358)$ emerged especially clearly as the most powerful agents of innovative work behavior. The relationships between these variables and innovation were positive in direction, sizeable in magnitude, and significant, and displayed validity generalization. These findings thus lend support to theories proposing these relationships, such as the theory of team adaptation (Burke et al., 2006) and the theory of team innovation (West \& Anderson, 1996). Management representatives and team leaders should consequently strive to provide their teams with clearly stated, visionary, and motivating higher order goals, provide high norms and support for innovative endeavors, and enhance team members' commitment to excellence by encouraging them to mutually monitor each other's performance and engage in constructive feedback. Communication —internally and externally_was introduced as a source of innovation over a quarter of a century ago (Visart, 1979). Our findings confirm that communication, especially with individuals outside one's own team, is a crucial element in fostering innovation in the workplace. If individuals maintain social relations with people outside their core work team, they are more likely to be exposed to new kinds of information and diverse viewpoints and thus generate fresh ideas. When various team members keep up relationships with different individuals or groups outside their team, the domain-relevant and procedural knowledge base of the whole team can be increased considerably, which in turn should enhance their ability to generate, test, and implement new solutions. Our findings also lend support to the propositions presented by Perry-Smith and Shalley (2003). Perry-Smith and Shalley divided social relationships into strong and weak ties (characterized by different amounts of interaction, emotional intensity, and reciprocity) and presented several arguments as to why weak ties should be better for creativity: Weak ties are more likely to be nonredundant and thereby give access to diverse information; they are more likely to connect people with different backgrounds and different perspectives and are less susceptible to group pressure and false consensus. Weak ties are probably more frequent with people outside one's own team, whereas internal team members are more likely to have stronger ties.

Interestingly, participative safety displayed only a weak relationship with innovation $(\rho=.148$ ). This might be due to the intragroup safety component of participative safety. If team members are highly committed to maintaining a nonthreatening atmosphere and a positive affective tone, they might be afraid of conflict and shy away from criticizing each others' ideas. Intragroup safety might therefore enhance social pressure, hinder autonomous thinking, and lead to conformity and groupthink (Janis, 1972), and this might well explain the low correlation between participative safety and innovation.

With regard to task and relationship conflict, our findings mirror the inconclusiveness of the research literature. Overall, the corrected correlation is slightly positive for task conflict $(\rho=.067)$ and slightly negative for relationship conflict $(\rho=-.092)$, but because credibility and confidence intervals include zero, those corrected correlations cannot be interpreted as an indicator of a generalizable main relationship between conflict and innovation. They clearly indicate that correlations in primary studies differ substantially in magnitude and direction. Especially for task conflict, primary studies report both negative and positive relationships with innovation. Apart from the expected positive effects of task conflict, there might thus be a downside to conflict, in that it might undermine effective group functioning (Kratzer et al., 2006; Lovelace et al., 2001). In a critical review of the conflict literature, De Dreu (2008) contended that conflict might serve positive functions only under very specific circumstances. Future studies should thus focus on exploring these contingencies under which task conflict helps or hinders innovation in the workplace. Some researchers have already started with this endeavor: It has been shown that intrateam disagreement affects innovation differently at different stages of the innovation process (Kratzer et al., 2006) and that the effect of task disagreement depends on the extent to which team members feel free to express doubts (Lovelace et al., 2001). 
Furthermore, it has been suggested that the relationship between task conflict and innovation follows an inverted U-shape (Anderson et al., 2004; De Dreu, 2006), with moderate levels of conflict being conducive to creative problem solving.

\section{Measurement Level and Measurement Method as Moderators}

After analyzing main relationships between team input and process variables and innovation, we proceeded to test whether measurement level and measurement method moderate those overall relationships. To guide these analyses, we introduced the concept of Type 1, Type 2, and Type 3 research designs in the innovation literature. Results confirmed that the relationship between team input and process variables and innovation depends on measurement level: Support for innovation, vision, task orientation, and external communication showed considerably stronger relationships with team innovation (Type 2 design) compared with individual innovation (Type 3 design). Thus, team members' perceptions of team processes affect the innovativeness of the whole team more than the innovativeness of individual team members. This finding suggests that predictor variables conceptually anchored at the team level are more strongly related to the criterioninnovation-if this is also measured and statistically treated at the team level of analysis. Our findings provide a quantification of the consequences of any incongruence between level of theory, level of measurement, and level of statistical analyses, and thereby provide strong empirical evidence for claims to carefully match these dimensions (Klein, Dansereau, \& Hall, 1994). We believe that this is the first contribution to have done so concerning the diverse and growing innovation literatures and that issues of levels of analysis require far greater attention and careful treatment in future innovation studies.

The second moderator we investigated was the type of criterion measure. Self-ratings of innovation displayed substantially higher effect sizes than independent ratings or objective criteria for all team process variables. Two major conclusions can be drawn from this: First, even if independent ratings or objective criteria serve to measure the criterion, support for innovation, vision, task orientation, cohesion, and internal and external communication are powerful predictors of innovation. However, the results provide a simple illustration of the overestimation of effect sizes if singlesource, mono-method, self-report data are used. The problems associated with self-report data and the susceptibility to response biases on the one hand and the problem of common method variance on the other hand are well documented (Podsakoff et al., 2003; Schmitt, 1994). As the majority of past published studies have relied upon self-reports of both predictor and outcome variables in innovation research, it is clear that these findings have considerably overestimated the effect sizes between team-level variables and innovativeness. This is a fundamental misunderstanding in our knowledge base. The findings presented in the present meta-analysis thus provide quantitative estimates of the likely effects of the limitations of such methodological shortcomings. Our findings are unambiguous in this regard; if team processes are assessed by the very same individuals who evaluate their own innovativeness, this almost inevitably leads to an overestimate of effect sizes. Although peer and supervisor ratings or objective measures are also far from being perfectly reliable and valid criterion measures (Howard, 1994), it is likely that greater reliance can be placed upon these measures than on self-reports. Innovation researchers should therefore switch their design orientations away from overly simplistic self-report designs toward the incorporation of independent and objective outcome measures in this domain (see also Anderson et al., 2004).

\section{Implications for Practice}

What implications for practice and the management of innovation in organizations arise from our series of findings? Interventions should focus on providing the group with high norms for innovation and creating a climate that is open to change and error friendly. To maintain high standards of task performance, team members as well as team leaders and higher management have to find a balance in truly supporting each other in developing and implementing new ideas and at the same time monitoring and critically appraising each other. Supervisors and team leaders should strive to provide the team with clearly stated, shared, and visionary goals. To ensure that team members cooperate and collaborate in working on those superordinate goals, team members should be interdependent in reaching their personal goals. This can be achieved by linking the provision of feedback and personal incentives to the accomplishment of group rather than individual goals. Finally, every effort should be made to enhance communication both internally and externally by analyzing the communication flow within the team and with stakeholders outside the team and by supporting the building of networks with other teams, departments, and even organizations.

\section{Limitations}

Although we believe that the present meta-analytic findings contribute to the innovation literature, some limitations should be considered in drawing conclusions from our results. First, some analyses are based on a comparatively small number of studies, especially in the subgroup analyses (e.g., objective measures of innovation). Although we acknowledge that estimates of the mean effect size are more accurate if based on a large number of original studies, even small meta-analyses provide meaningful and reliable insights into relations between variables (cf. Schmidt, Hunter, Pearlman, \& Hirsh, 1985, p. 749). Moreover, the fact that we identified variables that are allotted only a small number of studies ( $k$ ) also provides valuable insights into the state of the art of innovation research. A simple inspection of the number of studies per category in Tables 1 and 2 provides a valuable overview of which team-level variables deserve more attention in future studies of innovation. Second, we could not conduct complete moderator analyses for all 15 variables under investigation. Objective measures of innovative performance were used in only a minority of studies. This also points to important demands for future research: We should set higher standards for the use of criterion methods within innovation research. We therefore strongly recommend complementing self-report measures of innovation with ratings by independent judges and objective criteria to be able to assess and understand the biases associated with the different data sources.

\section{Conclusion}

To our knowledge, this is the first comprehensive meta-analysis of team-level antecedents of innovation to have appeared in the 
literature. Our sample of independent studies spans a 30-year period and is as comprehensive as it was feasible to achieve, including a number of unpublished studies, studies from a wide range of countries, and primary studies published in languages other than English. We were able to identify a set of team-level variables that display strong and generalizable relationships with innovation: vision, external communication, support for innovation, task orientation, internal communication, cohesion, and goal interdependence. As validity generalization was supported for all these variables, they can thus be expected to display distinct positive relationships with innovation, regardless of specific context characteristics. Our quantitative integration also revealed which variables do not display validity generalization. Obviously, it appears that these variables matter in some conditions but not in others. This finding is critical with regard to future creativity and innovation research, as it points to the need to focus on contingency models and to explore boundary conditions, moderator variables, and potential curvilinear effects within innovation processes and outcomes. Thus, in quantitatively summarizing over 30 years of primary studies at the individual and team levels of analysis, these findings will permit theory building and directions for future research to be based upon these key summary findings.

\section{References}

References marked with an asterisk indicate studies included in the meta-analysis

*Abbey, A., \& Dickson, J. W. (1983). R\&D work climate and innovation in semiconductors. Academy of Management Journal, 26, 362-368.

*Agrell, A., \& Gustafson, R. (1994). The Team Climate Inventory (TCI) and group innovation: A psychometric test on a Swedish sample of work groups. Journal of Occupational and Organizational Psychology, 67, 143-151.

Ainsworth, M. S. (1979). Infant-mother attachment. American Psychologist, 34, 832-937.

Amabile, T. M. (1996). Creativity in context. Boulder, CO: Westview Press.

*Amabile, T. M., Conti, R., Coon, H., Lazenby, J., \& Herron, M. (1996). Assessing the work environment for creativity. Academy of Management Journal, 39, 1154-1184.

Amabile, T. M., Mueller, J. S., Simpson, W. B., Hadley, C. N., Kramer, S. J., \& Fleming, L. (2002). Time pressure and creativity in organizations: A longitudinal field study. (HBS Working Paper 02-073). Cambridge, MA: Harvard University, Harvard Business School.

*Ancona, D. G., \& Caldwell, D. F. (1992a). Bridging the boundary: External activity and performance in organizational teams. Administrative Science Quarterly, 37, 634-665.

*Ancona, D. G., \& Caldwell, D. F. (1992b). Demography and design: Predictors of new product team performance. Organization Science, 3, 321-341.

Anderson, N., De Dreu, C. K. W., \& Nijstad, B. A. (2004). The routinization of innovation research: A constructively critical review of the state-of-the-science. Journal of Organizational Behavior, 25, 147-173.

Anderson, N., \& King, N. (1991). Managing innovation in organisations. Leadership \& Organisation Development Journal, 12, 17-21.

Anderson, N., \& King, N. (1993). Innovation in organizations. In C. L. Cooper \& I. T. Robertson (Eds.), International review of industrial and organizational psychology (pp. 1-34). Chichester, England: Wiley.

Anderson, N., \& West, M. A. (1998). Measuring climate for work group innovation: Development and validation of the team climate inventory. Journal of Organizational Behavior, 19, 235-258.

Andrews, J., \& Smith, D. C. (1996). In search of the marketing imagina- tion: Factors affecting the creativity of marketing programs for mature products. Journal of Marketing Research, 33, 174-187.

*Axtell, C. M., Holman, D. J., Unsworth, K. L., Wall, T. D., Waterson, P. E., \& Harrington, E. (2000). Shopfloor innovation: Facilitating the suggestion and implementation of ideas. Journal of Occupational and Organizational Psychology, 73, 265-285.

*Axtell, C. M., Holman, D. J., \& Wall, T. D. (2006). Promoting innovation: A change study. Journal of Occupational and Organizational Psychology, 79, 509-516.

*Baer, M., \& Oldham, G. R. (2006). The curvilinear relation between experienced creative time pressure and creativity: Moderating effects of openness to experience and support for creativity. Journal of Applied Psychology, 91, 963-970.

Baron, R. A. (1991). Positive effects of conflict: A cognitive perspective. Employee Responsibilities and Rights Journal, 4, 25-36.

*Bates, R., \& Khasawneh, S. (2005). Organizational learning culture, learning transfer climate and perceived innovation in Jordanian organizations. International Journal of Training and Development, 9, 96-109.

Beal, D. J., Cohen, R. R., Burke, M. J., \& McLendon, C. L. (2003). Cohesion and performance in groups: A meta-analytic clarification of construct relations. Journal of Applied Psychology, 88, 989-1004.

*Belschak, F., \& Den Hartog, D. N. (2007). Innovation and proactivity. Unpublished manuscript. University of Amsterdam.

Bledow, R., Frese, M., Anderson, N., Erez, M., \& Farr, J. (in press). A dialectic perspective on innovation: Conflicting demands, multiple pathways, and ambidexterity. Industrial and Organizational Psychology: Perspectives on Science and Practice.

Bouchard, T. J., \& Hare, M. (1970). Size, performance, and potential in brainstorming groups. Journal of Applied Psychology, 54, 51-55.

Brodbeck, F. C., Kerschreiter, R., Mojzisch, A., Frey, D., \& Schulz-Hardt, S. (2002). The dissemination of critical, unshared information in decision-making groups: The effects of pre-discussion dissent. European Journal of Social Psychology, 32, 35-56.

*Brodbeck, F. C., \& Maier, G. W. (2001). Das Teamklima-Inventar (TKI) für Innovation in Gruppen: Psychometrische Überprüfung an einer deutschen Stichprobe [The Team Climate Inventory for Innovation: A psychometric test on a German sample of work groups]. Zeitschrift für Arbeits- und Organisationspsychologie, 45, 59-73.

*Bunce, D., \& West, M. A. (1995). Self-perceptions and perceptions of group climate as predictors of individual innovation at work. Applied Psychology: An International Review, 44, 199-215.

Burke, C. S., Stagl, K. C., Salas, E., Pierce, L., \& Kendall, D. (2006). Understanding team adaptation: A conceptual analysis and model. Journal of Applied Psychology, 91, 1189-1207.

*Burningham, C., \& West, M. A. (1995). Individual, climate, and groupinteraction processes as predictors of work team innovation. Small Group Research, 26, 106-117.

*Cady, S. H., \& Valentine, J. (1999). Team innovation and perceptions of consideration: What difference does diversity make? Small Group Research, 30, 730-750.

*Caldwell, D. F., \& O'Reilly, C. A. (2003). The determinants of teambased innovation in organizations: The role of social influence. Small Group Research, 34, 497-517.

Camisón-Zornoza, C., Lapiedra-Alcamí, R., Segarra-Ciprés, M., \& Boronat-Navarro, M. (2004). A meta-analysis of innovation and organization size. Organization Studies, 25, 331-361.

Campion, M. A., Papper, E. M., \& Medsker, G. J. (1996). Relations between work team characteristics and effectiveness: A replication and extension. Personnel Psychology, 49, 429-452.

*Cardinal, L. B. (2001). Technological innovation in the pharmaceutical industry: The use of organizational control in managing research and development. Organization Science, 12, 19-36.

Carnevale, P. J., \& Probst, T. M. (1998). Social values and social conflict 
in creative problem solving and categorization. Journal of Personality and Social Psychology, 74, 1300-1309.

*Chen, M.-H. (2006). Understanding the benefits and detriments of conflict on team creativity process. Creativity and Innovation Management, $15,105-115$.

*Choi, J. N. (2004). Individual and contextual dynamics of innovation-use behavior in organizations. Human Performance, 17, 397-414.

*Clegg, C., Unsworth, K. L., Epitropaki, O., \& Parker, G. (2002). Implicating trust in the innovation process. Journal of Occupational and Organizational Psychology, 75, 409-422.

Cohen, J. (1988). Statistical power analysis for the behavioral sciences. Hillsdale, NY: Erlbaum.

Cumming, G., \& Finch, S. (2005). Inference by eye: Confidence intervals and how to read pictures of data. American Psychologist, 60, 170-180.

Damanpour, F. (1991). Organizational innovation: A meta-analysis of effects of determinants and moderators. Academy of Management Journal, 34, 555-590.

*De Dreu, C. K. W. (2002). Team innovation and team effectiveness: The importance of minority dissent and reflexivity. European Journal of Work and Organizational Psychology, 11, 285-298.

*De Dreu, C. K. W. (2006). When too little or too much hurts: Evidence for a curvilinear relationship between task conflict and innovation in teams. Journal of Management, 32, 83-107.

De Dreu, C. K. W. (2008). The virtue and vice of workplace conflict: Food for pessimistic thought. Journal of Organizational Behavior, 29, 5-18.

*De Dreu, C. K. W., \& West, M. A. (2001). Minority dissent and team innovation: The importance of participation in decision making. Journal of Applied Psychology, 86, 1191-1201.

*De Jong, J. P. J., \& Den Hartog, D. N. (2005). Determinanten van innovatief gedrag: Een onderzoek onder kenniswerkers in het $M K B$ [Determinants of innovative behavior: A study with knowledge workers]. Gedrag en Organisatie, 18, 235-259.

*Denison, D. R., Hart, S. L., \& Kahn, J. A. (1996). From chimneys to cross-functional teams: Developing and validating a diagnostic model. Academy of Management Journal, 39, 1005-1023.

Deutsch, M. (1969). Conflicts: Productive and destructive. Journal of Social Issues, 25, 7-41.

Deutsch, M. (1973). The resolution of conflict: Constructive and destructive processes. New Haven, CT: Yale University Press.

*Dorenbosch, L., Van Engen, M. L., \& Verhagen, M. (2005). On-the-job innovation: The impact of job design and human resource management through production ownership. Creativity and Innovation Management, 14, 129-141.

*Drach-Zahavy, A., \& Somech, A. (2001). Understanding team innovation: The role of team processes and structures. Group Dynamics: Theory, Research, and Practice, 5, 111-123.

Edmondson, A. (1999). Psychological safety and learning behavior in work teams. Administrative Science Quarterly, 44, 350-383.

*Eisenberg, J. (2003, May). The effects of the interaction between group cohesiveness and type of rewards on creative performance in simulated project teams. Paper presented at the 11th European Congress of Work and Organizational Psychology, Lisbon, Portugal

*Ettlie, J. E., \& O'Keefe, R. D. (1982). Innovative attitudes, values, and intentions in organizations. Journal of Management Studies, 19, 163182.

*Farmer, S. M., Tierney, P., \& Kung-McIntyre, K. (2003). Employee creativity in Taiwan: An application of role identity theory. Academy of Management Journal, 46, 618-630.

*Fay, D., Borrill, C. S., Amir, Z., Haward, R., \& West, M. A. (2006). Getting the most out of multidisciplinary teams: A multi-sample study of team innovation in health care. Journal of Occupational and Organizational Psychology, 79, 553-567.

*Feij, J. A., Whitley, W. T., Peiro, J. M., \& Taris, T. W. (1995). The development of career-enhancing strategies and content innovation: A longitudinal study of new workers. Journal of Vocational Behavior, 46, 231-256.

Festinger, L. (1950). Informal social communication. Psychological Review, 57, 271-282.

Frese, M., Teng, E., \& Wijnen, C. J. D. (1999). Helping to improve suggestion systems: Predictors of making suggestions in companies. Journal of Organizational Behavior, 20, 1139-1155.

Gallupe, R. B., Dennis, A. R., Cooper, W. H., Valacich, J. S., Bastianutti, L. M., \& Nunamaker, J. F. (1992). Electronic brainstorming and groupsize. Academy of Management Journal, 35, 350-369.

*Gasteiger, R. M., \& Anderson, N. (2007). [Promoting innovation and well-being at work]. Unpublished raw data.

*George, J. M., \& Zhou, J. (2001). When openness to experience and conscientiousness are related to creative behavior: An interactional approach. Journal of Applied Psychology, 86, 513-524.

*Gerritsen, M. (2006). What makes people innovative in their work? Unpublished master's thesis, University of Amsterdam, Amsterdam, The Netherlands.

Gilson, L. L., \& Shalley, C. E. (2004). A little creativity goes a long way: An examination of teams' engagement in creative processes. Journal of Management, 30, 453-470.

Gooding, R. Z., \& Wagner, J. A. (1985). A meta-analytic review of the relationship between size and performance: The productivity and efficiency of organizations and their subunits. Administrative Science Quarterly, 30, 462-481.

*Griffin, M. A., Neal, A., \& Parker, S. K. (2007). A new model of work role performance: Positive behavior in uncertain and interdependent contexts. Academy of Management Journal, 50, 327-347.

*Griffith-Hemans, J., \& Grover, R. (2006). Setting the stage for creative new products: Investigating the idea fruition process. Journal of the Academy of Marketing Science, 34, 27-39.

Gully, S. M., Devine, D. J., \& Whitney, D. J. (1995). A meta-analysis of cohesion and performance: Effects of level of analysis and task interdependence. Small Group Research, 26, 497-520.

Hackman, J. R. (1987). The design of work teams. In J. W. Lorsch (Ed.), Handbook of organizational behavior (pp. 315-342). Englewood Cliffs, NJ: Prentice-Hall.

*Hoegl, M., \& Gemuenden, H. G. (2001). Teamwork quality and the success of innovative projects: A theoretical concept and empirical evidence. Organization Science, 12, 435-449.

*Hoegl, M., Weinkauf, K., \& Gemuenden, H. G. (2004). Interteam coordination, project commitment, and teamwork in multiteam R\&D projects: A longitudinal study. Organization Science, 15, 38-55.

Howard, H. S. (1994). Why do people say nasty things about self-reports. Journal of Organizational Behavior, 15, 399-404.

Hunter, J. E., \& Schmidt, F. L. (2004). Methods of meta-analysis: Correcting error and bias in research findings. Thousand Oaks, CA: Sage.

Ilgen, D. R., Hollenbeck, J. R., Johnson, M., \& Jundt, D. (2005). Teams in organizations: From input-process-output models to IMOI models. Annual Review of Psychology, 56, 517-543.

Janis, I. (1972). Victims of groupthink: Psychological studies of policy decisions and fiascoes. Boston: Houghton Mifflin.

Jehn, K. A. (1995). A multimethod examination of the benefits and detriments of intragroup conflict. Administrative Science Quarterly, 40, $256-282$.

*Johnson, J. D., La France, B. H., \& Meyer, M. (1998). The impact of formalization, role conflict, role ambiguity, and communication quality on perceived organizational innovativeness in the cancer information service. Evaluation \& the Health Professions, 21, 27-51.

*Johnson, J. D., Meyer, M. E., Berkowitz, J. M., Ethington, C. T., \& Miller, V. D. (1997). Testing two contrasting structural models of innovativeness in a contractual network. Human Communication Research, 24, 320-348.

Judge, T. A., Colbert, A. E., \& Ilies, R. (2004). Intelligence and leadership: 
A quantitative review and test of theoretical propositions. Journal of Applied Psychology, 89, 542-552.

*Jung, D. I., Chow, C., \& Wu, A. (2003). The role of transformational leadership in enhancing organizational innovation: Hypotheses and some preliminary findings. Leadership Quarterly, 14, 525-544.

Katz, R. (1982). The effects of group longevity on project communication and performance. Administrative Science Quarterly, 27, 81-104.

*Kauffeld, S., Jonas, E., Grote, S., Frey, D., \& Frieling, E. (2004). Innovationsklima: Konstruktion und erste psychometrische Überprüfung eines Messinstrumentes [Climate for innovation: Creation and first psychometric validation of an instrument for measuring the climate for innovation in organizations]. Diagnostica, 50, 153-164.

*Keller, R. T. (2001). Cross-functional project groups in research and new product development: Diversity, communications, job stress, and outcomes. Academy of Management Journal, 44, 547-555.

*Keller, R. T., Julian, S. D., \& Kedia, B. L. (1996). A multinational study of work climate, job satisfaction, and the productivity of R\&D teams. IEEE Transactions on Engineering Management, 43, 48-55.

Kimberly, J. R., \& Evanisko, M. J. (1981). Organizational innovation: The influence of individual, organizational, and contextual factors on hospital adoption of technological and administrative innovations. Academy of Management Journal, 24, 689-713.

King, N., \& Anderson, N. (1990). Innovation in working groups. In M. A. West \& J. L. Farr (Eds.), Innovation and creativity at work: Psychological and organizational strategies (pp. 81-100). Chichester, England: Wiley.

King, N., Anderson, N., \& West, M. A. (1991). Organizational innovation: A case study into perceptions and processes. Work and Stress, 5, 331-339.

Klein, K. J., Dansereau, F., \& Hall, R. J. (1994). Levels issues in theory development, data-collection, and analysis. Academy of Management Review, 19, 195-229.

Kozlowski, S. W. J., \& Bell, B. S. (2003). Work groups and teams in organizations. In R. J. Klimoski, W. C. Borman, \& D. R. Ilgen (Eds.), Handbook of psychology: Vol. 12. Industrial and organizational psychology (pp. 333-375). New York: Wiley.

Kozlowski, S. W. J., \& Ilgen, D. R. (2006). Enhancing the effectiveness of work groups and teams. Psychological Science in the Public Interest, 7 , $77-124$.

*Kratzer, J., Leenders, R. T. A. J., \& Van Engelen, J. M. L. (2004). Stimulating the potential: Creative performance and communication in innovation teams. Creativity and Innovation Management, 13, 63-71.

*Kratzer, J., Leenders, R. T. A. J., \& Van Engelen, J. M. L. (2006). Team polarity and creative performance in innovation teams. Creativity and Innovation Management, 15, 96-104.

*Krause, D. E., \& Gebert, D. (2006). Effekte von interpersonalen Konflikten und Widerstand von Führungskräften auf die Implementierung von Verfahrensinnovationen [Effects of interpersonal conflicts and management resistance on the implementation of process innovations]. Zeitschrift für Personalforschung, 20, 102-120.

*Kurtzberg, T. R. (2005). Feeling creative, being creative: An empirical study of diversity and creativity in teams. Creativity Research Journal, $17,51-65$.

*Kurtzberg, T. R., \& Mueller, J. S. (2005). The influence of daily conflict on perceptions of creativity: A longitudinal study. International Journal of Conflict Management, 16, 335-353.

*Langer, P., Duncan, E., \& Rassen, R. L. (1980). Factors contributing to large-scale instructional development. Psychological Reports, 47, 147154

*LePine, J. A., \& Van Dyne, L. (1998). Predicting voice behavior in work groups. Journal of Applied Psychology, 83, 853-868.

Lott, A. J., \& Lott, B. E. (1965). Group cohesiveness as interpersonal attraction: A review of relationships with antecedent and consequent variables. Psychological Bulletin, 64, 259-309.
*Lovelace, K., Shapiro, D. L., \& Weingart, L. R. (2001). Maximizing cross-functional new product teams' innovativeness and constraint adherence: A conflict communications perspective. Academy of Management Journal, 44, 779-793.

*Madjar, N. (in press). Emotional and informational support from different sources and employee creativity. Journal of Occupational and Organizational Psychology.

*Madjar, N., Oldham, G. R., \& Pratt, M. G. (2002). There's no place like home? The contributions of work and nonwork creativity support to employees' creative performance. Academy of Management Journal, 45, $757-767$.

Maier, G. W., Streicher, B., Jonas, E., \& Frey, D. (2007). Innovation und Kreativität [Innovation and creativity]. In L. von Rosenstiel \& D. Frey (Eds.), Enzyklopädie der Psychologie, Band Wirtschaftspsychologie [Encyclopedia of psychology, industrial psychology] (pp. 809-855). Göttingen, Germany: Hogrefe.

Mathisen, G. E., Einarsen, S., Jorstad, K., \& Bronnick, K. S. (2004). Climate for work group creativity and innovation: Norwegian validation of the Team Climate Inventory (TCI). Scandinavian Journal of Psychology, 45, 383-392.

* Meissner, W. (1988). Innovationen in Organisationen [Innovations in organizations]. Zeitschrift für Arbeits- und Organisationspsychologie, $32,174-183$.

Milliken, F. J., \& Martins, L. L. (1996). Searching for common threads: Understanding the multiple effects of diversity in organizational groups. Academy of Management Review, 21, 402-433.

*Miron, E., Erez, M., \& Naveh, E. (2004). Do personal characteristics and cultural values that promote innovation, quality, and efficiency compete or complement each other? Journal of Organizational Behavior, 25, 175-199.

*Mohamed, M. A. K. (2002). Assessing determinants of departmental innovation. Personnel Review, 31, 620-641.

*Morrison, E. W., \& Phelps, C. C. (1999). Taking charge at work: Extrarole efforts to initiate workplace change. Academy of Management Journal, 42, 403-419.

Mosier, C. I. (1943). On the reliability of a weighted composite. Psychometrika, 8, 161-168.

Mullen, B., \& Copper, C. (1994). The relation between group cohesiveness and performance: An integration. Psychological Bulletin, 115, 210-227.

Mumford, M. D., \& Licuanan, B. (2004). Leading for innovation: Conclusions, issues, and directions. Leadership Quarterly, 15, 163-171.

Mumford, M. D., Scott, G. M., Gaddis, B., \& Strange, J. M. (2002). Leading creative people: Orchestrating expertise and relationships. Leadership Quarterly, 13, 705-750.

*Nijstad, B. A., Selman, F., \& De Dreu, C. K. W. (2007). Minority dissent and innovation in top management teams. Manuscript submitted for publication.

Ohly, S., Sonnentag, S., \& Pluntke, F. (2006). Routinization, work characteristics and their relationships with creative and proactive behaviors. Journal of Organizational Behavior, 27, 257-279.

Oldham, G. R., \& Cummings, A. (1996). Employee creativity: Personal and contextual factors at work. Academy of Management Journal, 39, $607-634$

*Ong, C. H., Wan, D., \& Chng, S. H. (2003). Factors affecting individual innovation: An examination within a Japanese subsidiary in Singapore. Technovation, 23, 617-631.

*Orpen, C. (1990). Measuring support for organizational innovation: A validity study. Psychological Reports, 67, 417-418.

*Parker, S. K., Williams, H. M., \& Turner, N. (2006). Modeling the antecedents of proactive behavior at work. Journal of Applied Psychology, 91, 636-652.

Patterson, F. (2002). Great minds don't think alike? Person-level predictors of innovation at work. In C. L. Cooper \& I. T. Robertson (Eds.), 
International review of industrial and organizational psychology (pp. 115-144). Chichester, England: Wiley.

*Patterson, M. G., West, M. A., Shackleton, V. J., Dawson, J. F., Lawthom, R., Maitlis, S., et al. (2005). Validating the organizational climate measure: Links to managerial practices, productivity and innovation. Journal of Organizational Behavior, 26, 379-408.

Payne, R. (1990). The effectiveness of research teams: A review. In M. A. West \& J. L. Farr (Eds.), Innovation and creativity at work: Psychological and organizational strategies (pp. 101-122). Chichester, England: Wiley.

*Pearce, C. L., \& Ensley, M. D. (2004). A reciprocal and longitudinal investigation of the innovation process: The central role of shared vision in product and process innovation teams (PPITs). Journal of Organizational Behavior, 25, 259-278.

Pelled, L. H. (1996). Demographic diversity, conflict, and work group outcomes: An intervening process theory. Organization Science, 7 , 615-631.

*Pelled, L. H., Eisenhardt, K. M., \& Xin, K. R. (1999). Exploring the black box: An analysis of work group diversity, conflict, and performance. Administrative Science Quarterly, 44, 1-28.

*Perry-Smith, J. E. (2006). Social yet creative: The role of social relationships in facilitating individual creativity. Academy of Management Journal, 49, 85-101.

Perry-Smith, J. E., \& Shalley, C. E. (2003). The social side of creativity: A static and dynamic social network perspective. Academy of Management Review, 29, 89-106.

*Pirola-Merlo, A., \& Mann, L. (2004). The relationship between individual creativity and team creativity: Aggregating across people and time. Journal of Organizational Behavior, 25, 235-257.

Podsakoff, P. M., MacKenzie, S. B., Lee, J. Y., \& Podsakoff, N. P. (2003). Common method biases in behavioral research: A critical review of the literature and recommended remedies. Journal of Applied Psychology, 88, 879-903.

*Politis, J. D. (2005). Dispersed leadership predictor of the work environment for creativity and productivity. European Journal of Innovation Management, 8, 182-204.

Ragazzoni, R., Baiardi, P., Zotti, A. M., Anderson, N., \& West, M. (2002). Italian validation of the team climate inventory: A measure of team climate for innovation. Journal of Managerial Psychology, 17, 325-336.

*Rickards, T., Chen, M. H., \& Moger, S. (2001). Development of a self-report instrument for exploring team factor, leadership and performance relationships. British Journal of Management, 12, 243-250.

Saavedra, R., Earley, P. C., \& Van Dyne, L. (1993). Complex interdependence in task-performing groups. Journal of Applied Psychology, 78, $61-72$.

Salas, E., Stagl, K. C., \& Burke, C. S. (2004). 24 years of team effectiveness in organizations: Research themes and emerging needs. International Review of Industrial and Organizational Psychology, 19, 47-91.

*Schepers, P., \& Van den Berg, P. T. (2007). Social factors of workenvironment creativity. Journal of Business and Psychology, 21, 407428.

Schmidt, F. L., Hunter, J. E., Pearlman, K., \& Hirsh, H. R. (1985). Forty questions about validity generalization and meta-analysis. Personnel Psychology, 38, 697-798.

Schmitt, N. (1994). Method bias: The importance of theory and measurement. Journal of Organizational Behavior, 15, 393-398.

*Schulze, A., \& Hoegl, M. (2006). Knowledge creation in new product development projects. Journal of Management, 32, 210-236.

*Scott, S. G., \& Bruce, R. A. (1994). Determinants of innovative behavior: A path model of individual innovation in the workplace. Academy of Management Journal, 37, 580-607.

Seashore, S. A. (1954). Group cohesiveness in the industrial work group. Ann Arbor, MI: University of Michigan Press.

*Sethi, R., Smith, D. C., \& Park, C. W. (2001). Cross-functional product development teams, creativity, and the innovativeness of new consumer products. Journal of Marketing Research, 38, 73-85.

Shalley, C. E. (1995). Effects of coaction, expected evaluation, and goal setting on creativity and productivity. Academy of Management Journal, $38,483-503$.

Shalley, C. E. (2002). How valid and useful is the integrative model for understanding work groups' creativity and innovation? Applied Psychology: An International Review, 51, 406-410.

Shalley, C. E., \& Gilson, L. L. (2004). What leaders need to know: A review of social and contextual factors that can foster or hinder creativity. Leadership Quarterly, 15, 33-53.

Shalley, C. E., \& Perry-Smith, J. E. (2001). Effects of socia-psychological factors on creative performance: The role of informational and controlling expected evaluation and modeling experience. Organizational Behavior and Human Decision Processes, 84, 1-22.

Shalley, C. E., Zhou, J., \& Oldham, G. R. (2004). The effects of personal and contextual characteristics on creativity: Where should we go from here? Journal of Management, 30, 933-958.

*Shin, S. J., \& Zhou, J. (2003). Transformational leadership, conservation, and creativity: Evidence from Korea. Academy of Management Journal, 46, 703-714.

*Somech, A. (2006). The effects of leadership style and team process on performance and innovation in functionally heterogeneous teams. Journal of Management, 32, 132-157.

*Song, M., Dyer, B., \& Thieme, R. J. (2006). Conflict management and innovation performance: An integrated contingency perspective. Journal of the Academy of Marketing Science, 34, 341-356.

*Spreitzer, G. M. (1995). An empirical test of a comprehensive model of intrapersonal empowerment in the workplace. American Journal of Community Psychology, 23, 601-629.

Stanne, M. B., Johnson, D. W., \& Johnson, R. T. (1999). Does competition enhance or inhibit motor performance: A meta-analysis. Psychological Bulletin, 125, 133-154.

Stewart, G. L. (2006). A meta-analytic review of relationships between team design features and team performance. Journal of Management, 32, $29-55$.

*Swailes, S. (2004). Commitment to change: Profiles of commitment and in-role performance. Personnel Review, 33, 187-204.

Tierney, P., Farmer, S. M., \& Graen, G. B. (1999). An examination of leadership and employee creativity: The relevance of traits and relationships. Personnel Psychology, 52, 591-620.

*Tiwana, A., \& McLean, E. R. (2005). Expertise integration and creativity in information systems development. Journal of Management Information Systems, 22, 13-43.

Tjosvold, D. (1985). Implications of controversy research for management. Journal of Management, 11, 21-37.

*Tjosvold, D., Tang, M. M. L., \& West, M. (2004). Reflexivity for team innovation in China. Group and Organization Management, 29, 540 559.

*Tsai, W. P. (2001). Knowledge transfer in intraorganizational networks: Effects of network position and absorptive capacity on business unit innovation and performance. Academy of Management Journal, 44, 996-1004.

*Tsai, W. P., \& Ghoshal, S. (1998). Social capital and value creation: The role of intrafirm networks. Academy of Management Journal, 41, 464476.

Van der Vegt, G., Emans, B., \& Van de Vliert, E. (1999). Effects of interdependencies in project teams. Journal of Social Psychology, 139, 202-214.

*Van der Vegt, G. S., \& Janssen, O. (2003). Joint impact of interdependence and group diversity on innovation. Journal of Management, 29, $729-751$.

Van der Vegt, G., \& Van de Vliert, E. (2002). Intragroup interdependence 
and effectiveness: Review and proposed directions for theory and practice. Journal of Managerial Psychology, 17, 50-67.

Van de Ven, A. (1986). Central problems in the management of innovation. Management Science, 32, 590-607.

*Vera, D., \& Crossan, M. (2005). Improvisation and innovative performance in teams. Organization Science, 16, 203-224.

Visart, N. (1979). Communication between and within research units. In F. M. Andrews (Ed.), Scientific productivity (pp. 223-251). Cambridge, England: Cambridge University Press.

Wageman, R. (1995). Interdependence and group effectiveness. Administrative Science Quarterly, 40, 145-180.

*Watson, W. E., Kumar, K., \& Michaelsen, L. K. (1993). Cultural diversity's impact on interaction process and performance: Comparing homogeneous and diverse task groups. Academy of Management Journal, 36, 590-602

Webber, S. S., \& Donahue, L. M. (2001). Impact of highly and less job-related diversity on work group cohesion and performance: A metaanalysis. Journal of Management, 27, 141-162.

West, M. A. (1990). The social psychology of innovation in groups. In M. A. West \& J. L. Farr (Eds.), Innovation and creativity at work (pp. 309-333). Chichester, England: Wiley.

West, M. A. (2002). Sparkling fountains or stagnant ponds: An integrative model of creativity and innovation implementation in work groups. Applied Psychology: An International Review, 51, 355-424.

*West, M. A., \& Anderson, N. R. (1996). Innovation in top management teams. Journal of Applied Psychology, 81, 680-693.

*West, M. A., Borrill, C. S., Dawson, J. F., Brodbeck, F. C., Shapiro,
D. A., \& Haward, B. (2003). Leadership clarity and team innovation in health care. Leadership Quarterly, 14, 393-410.

West, M. A., \& Farr, J. L. (1989). Innovation at work: Psychological perspectives. Social Behaviour, 4, 15-30.

West, M. A., \& Farr, J. L. (1990). Innovation at work. In M. A. West \& J. L. Farr (Eds.), Innovation and creativity at work: Psychological and organizational strategies (pp. 3-13). Chichester, England: Wiley.

*West, M. A., \& Wallace, M. (1991). Innovation in health care teams. European Journal of Social Psychology, 21, 303-315.

Whitener, E. M. (1990). Confusion of confidence-intervals and credibility intervals in meta-analysis. Journal of Applied Psychology, 75, 315-321.

*Wong, A., Tjosvold, D., \& Su, F. (2007). Social face for innovation in strategic alliances in China: The mediating roles of resource exchange and reflexivity. Journal of Organizational Behavior, 28, 961-978.

Woodman, R. W., Sawyer, J. E., \& Griffin, R. W. (1993). Toward a theory of organizational creativity. Academy of Management Review, 18, 293321.

*Yap, C.-M., Chai, K.-H., \& Lemarie, P. (2005). An empirical study on functional diversity and innovation in SMEs. Creativity and Innovation Management, 14, 176-190.

*Zhou, J., \& George, J. M. (2001). When job dissatisfaction leads to creativity: Encouraging the expression of voice. Academy of Management Journal, 44, 682-696.

Received June 17, 2008

Revision received March 9, 2009

Accepted March 11, 2009

\section{New Editors Appointed, 2011-2016}

The Publications and Communications Board of the American Psychological Association announces the appointment of 3 new editors for 6-year terms beginning in 2011. As of January 1, 2010, manuscripts should be directed as follows:

- Developmental Psychology (http://www.apa.org/journals/dev), Jacquelynne S. Eccles, PhD, Department of Psychology, University of Michigan, Ann Arbor, MI 48109

- Journal of Consulting and Clinical Psychology (http://www.apa.org/journals/ccp), Arthur M. Nezu, PhD, Department of Psychology, Drexel University, Philadelphia, PA 19102

- Psychological Review (http://www.apa.org/journals/rev), John R. Anderson, PhD, Department of Psychology, Carnegie Mellon University, Pittsburgh, PA 15213

Electronic manuscript submission: As of January 1, 2010, manuscripts should be submitted electronically to the new editors via the journal's Manuscript Submission Portal (see the website listed above with each journal title).

Manuscript submission patterns make the precise date of completion of the 2010 volumes uncertain. Current editors, Cynthia García Coll, PhD, Annette M. La Greca, PhD, and Keith Rayner, $\mathrm{PhD}$, will receive and consider new manuscripts through December 31, 2009. Should 2010 volumes be completed before that date, manuscripts will be redirected to the new editors for consideration in 2011 volumes. 